(C) 2020 Katedra Białorutenistyki UW. Wydanie w otwartym dostępie na licencji CC BY-NC-ND (https://creativecommons.org/licenses/by-nc-nd/4.0/deed.pl)

ACTA ALBARUTHENICA 20: 2020

DOI: $10.32612 /$ uw.18988091.2020.20.pp.25-66

Мікола Хаўстовіч/ Mikałaj Chaustowicz

Uniwersytet Warszawski / University of Warsaw ORCID: https://orcid.org/0000-0002-3007-0603

e-mail: m.khaustovich@uw.edu.pl

\title{
Выданні і рукапісы Гутаркі старога Дзеда
}

Editions and Manuscripts of CONVERSATIONS OF THE OLD GRANDFATHER

Wydania i rękopisy GAWĘDY STAREGO DZIADA

3 даследаванняў Генадзя Кісялёва і Зінаіды Тальвірскае мы ведалі, што Гутарка старога Дзеда была дастаткова папулярнаю ў першай палове 1860 -х гадоў, што захаваліся “шматлікія” (sic!) друкаваныя асобнікі, а таксама рукапісныя копіі ў бібліятэках і архівах. Вядома таксама, што “парыжскае” выданне твора мелася ў зборах Вінцэнта Мяніцкага: у чэрвені 1889 г. Браніслаў Эпімах-Шыпіла перапісаў Гутарку... у Селігорах, а пазней уключыў яе ў сваю Biełarusskuju Chrestomatiju [Хаўстовіч 2017: 217-222, 269-270]. У 1890-я гады (пра час мяркуем на падставе матэрыялаў, якія знаходзяцца побач) атрымаў у свае зборы копію (у самаробным сшытку) таго самага “парыжскага" выдання” Аляксандар Ельскі [AGAD 378, 1401, k. 184-194]. Два друкаваныя выданні - “парыжскае” і “пазнанскае” - ведаў Яўхім Карскі: пра іх ён паведаміў (і коратка ахарактарызаваў) спачатку ў першым томе Бълоруссовъ [1903: 443-445], а пасля ў трэцяй частцы трэцяга тома [1922: 86-87]. На жаль, навуковец не паінфармаваў пра месцазнаходжанне выкарыстаных асобнікаў твора.

Згадка Рамуальда Зямкевіча пра Вінцэся Каратынскага як аўтара Гутаркі... [Земкевіч 1918: 17], згаданыя публікацыі Я. Карскага, а таксама (мажліва) архіў Гальяша Леўчыка сталіся для Максіма Гарэцкага падставаю дзеля ўключэння твора ў раздзел Вінцэсь Каратынскі ў Хрыстаматыі беларускае літаратуры [1922: 172] і, вядома, у Гісторыю беларускае літаратуры [Гарэцкі 1920: 93-94]. Больш дакладна гісторык літаратуры крыніцаў не называе, але не складана здагадацца, што дзеля Гісторыі... ён выкарыстаў цытаты з кніг Я. Карскага, а вось на патрэбы Хрыстаматыі... адаптаваў нейкі невядомы сёння рукапіс (магчыма, са збораў Г. Леўчыка) ${ }^{1}$. Характарыстыка твора ў М. Гарэцка-

1 у Хрыстаматыі [1922: 172] М. Гарэцкі падае катрэн “Там лоб голяць і муштруюць...", які ёсць толькі ў двух даступных нам сёння тэкстах Гутаркі...: у “Dzienniku Literackim” і г. зв. "уроцлаўскім” рукапісе. 
га - у духу сацыялістычных ідэалаў эпохі; падкрэсліваецца таксама адсутнасць у творы ўласнабеларускага патрыятычнага складніка:

Заданьні брошуркі - рэволюцыйна-агітацыйныя, але ня столькі беларускія, сколькі польскія. Аўтар кажа аб дужа цяжкой долі беларускага народу пад маскальскім уціскам, пералічвае, колькі ёсьць рознага ліха і бяды ад яго: як падаткі, рэкруцкая павіннасьць, чыноўнікі, адбіраньне касьцёлаў на цэрквы і г. д.; даводзіць, што ў Сэвастопальскую вайну французы ішлі ратаваць палякоў і беларусаў; засьцерагае, каб ня мелі веры папом, быццам маскалі скасуюць паншчыну і г. д., - а ўсё гэта робіць дзеля таго, каб усе беларусы пашлі разам з палякамі, як толькі на вясну “гранець пранцуз, паляк 3 жаўнярамі"1. Ён пацяшае, што пайшоўшы 3 палякамі, “будзем роўныя з панамі” [Гарэцкі 1926: 140].

Наступнае пакаленне беларускіх гісторыкаў і літаратуразнаўцаў амаль не згадвала ў сваіх працах Гутарку.., бо ў эпоху вульгарнага сацыялагізму падобныя тэксты ўспрымаліся адназначна негатыўна:

Польскія памешчыкі ў саюзе з апалячанымі беларускімі памешчыкамі і інтэлігентамі ў імя таго, каб у барацьбе з Расіяй схіліць на свой бок беларускіх сялян, выдаюць рад “беларускіх твораў” антырускага характару2. У перыяд падрыхтоўкі да польскага паўстання ў 1861-1862 гг. былі распаўсюджаны на беларускай мове такія “творы”, як: Гутарка двух суседаў, Гутарка старога дзеда, Перадсмяротны разгавор Пустэльніка Пятра, які жыў пушчы дзевяцьдзесяць год, а памёр маючы сто сорак год, Крыўда і праўда, Гутарка беларуская і іншыя. Усе гэтыя “творы” напісаны па спецыяльнаму заказу польскіх памешчыкаў і адыгрывалі пэўную соцыяльную ролю. Гэта роля заключалася ў тым, каб пасеяць нацыянальную варожасць паміж рускім і беларускім народамі, узбудзіць нянавісць да Расіі і рускага народа і ўнушыць беларускаму селяніну ілжывую думку, што ён не знойдзе сабе нідзе для сябе лепшай ўлады, чым улада польскіх памешчыкаў. Тут часам знешне робіцца спроба выкрыцця царызма, але дзесяткі разоў паўтараемае слова "маскаль" выдае яго аўтараў з галавой як прагніўшых нацыяналістаў, змешваючых царскае, урадавае з усім рускім [Лушчыцкі 1958: 167].

Вяртанню Гутаркі... ў кантэкст беларускае літаратуры паспрыялі юбілейныя мерапрыемствы, звязаныя з угодкамі Powstania Styczniowego - Восстания 1863 года, якія ў 1963 годзе адзначаліся на дзяржаўным узроўні і, апрача таго, мелі шырокую навукова-даследчую і выдавецкую праграму, што распрацавалі Акадэмія навук ССCP, Polska Akademia Nauk, а таксама Акадэміі навук ЛітССР, БССР і УССР.

1 Гэты радок ёсць толькі ў “парыжскім” выданні Hutarki....

2 Іван Лушчыцкі размяжоўваў, аднак, “беларускія творы” “польскіх памешчыкаў” і “Мужыцкую праўду” Кастуся Каліноўскага. Сённяшнія прарасейскія публіцысты і “гісторыкі” Беларусі гэтага ўжо не робяць: “«Мужицкая правда» <...> призывала к борьбе против русских. Причем не только против русской администрации, а против всех русских. Листовка обращалась к крестьянам не с этнических позиций, в ней не было упоминания, что местные крестьяне - белорусы или литвины". Гл.: [Гронский 2005: 224-233]. 
У 1961 г. у беларускамоўным друку з'явіліся два надзвычай важныя артыкулы, у якіх - згодна з трактоўкай Паўстання 1863 года як вызваленчай барацьбы народаў былое Рэчы Паспалітае - давалася цалкам станоуччая характарыстыка Гутаркі... і рабіліся спробы атрыбуцыі твора. Абодва даследнікі не былі звязаныя з беларускім акадэмічным асяродкам: Мацей Канапацкі працаваў у беластоцкай “Ніве”, а Генадзь Кісялёў - у Цэнтральным дзяржаўным гістарычным архіве Літоўскай ССР. Склалася парадаксальная сітуацыя: тэкст "прагніўшых нацыяналістаў", ужо, хіба, канчаткова асуджаны на забыццё1, раптам займеў ажно двух - і не абыякіх! - аўтараў: Г. Кісялёў падаваў важкія аргументы на карысць таго, што Гутарка... належыць пяру Вінцэнта ДунінаМарцінкевіча [Кісялёў 1961: 119-138], а М. Канапацкі не менш пераканаўча сцвярджаў, што напісаная была яна Вінцэсем Каратынскім [Канапацкі 1961].

Гіпотэза М. Канапацкага, асцярожна² падтрыманая шэрагам публікацый маладога, але ўжо аўтарытэтнага Адама Мальдзіса [1968: 73-74], стала дамінавальнай у беларускім літаратуразнаўстве: укладальнікі ўніверсітэцкае хрэстаматыі ўключылі ў сваё выданне [Беларуская літаратура ХIX стагоддзя 1971: 119-120] фрагменты тэксту Гутаркі... з Хрыстаматыі... М. Гарэцкага, а Уладзімір Мархель змясціў 72 радкі 3 “парыжскага" выдання ў томіку твораў В. Каратынскага (у раздзеле Творы, якія прыпісвающца В. Каратынскаму) [1981: 153-155, 171].

Упершыню цалкам у беларускім друкуз Гутарка... была ўзноўленая ў часопісе “Спадчына” у 1999 г. [Хаўстовіч 1999: 86-105]. Тэкст падаваўся паводле "парыжскага" выдання з далучэннем у спасылках варыянтаў львоўскае газеты “Dziennik Literacki” і “кракаўскага" рукапісу.

У 2008 г., як твор В. Дуніна-Марцінкевіча, Гутарку... ўключыў Язэп Янушкевіч у Збор твораў у двух тамах (раздзел Dubia) Беларускага Дудара. Тут выкарыстоўваецца “парыжскае" выданне4; укладальнік падае тэкст як лацінкаю5, так і транслітараваны яго варыянт [Дунін-Марцінкевіч 2008: 500-512]. Дадзеная публікацыя была перадрукаваная

${ }^{1}$ Мяркуем па тым, што Гутарку..., а таксама шэраг іншых паўстанцкіх твораў нават не згадаў у сваёй манаграфіі тагачасны дырэктар Інстытута літаратуры Акадэміі навук БССР Васіль Барысенка [1957].

2 Гутарка... аднесена даследнікам да “твораў польскай арыентацыі", якія, нягледзячы на тое, што ў іх "асабліва выразна праявіліся шляхецка-нацыяналістычныя і рэлігійна-містычныя погляды правага крыла польскага вызваленчага руху", "нельга адносіць <...> да твораў выключна рэакцыйных. Крытыкай існуючых парадкаў яны ўзмацнялі ў сялян пачуццё варожасці да прыгонніцтва і самадзяржаўя" [Гл.: Мальдзіс 1969: 53-54].

3 У 1925 г. Аўгусцінас Янулайціс перадрукаваў літаграфію паводле рукапісу, які захоўваўся ў Бібліятэцы Урублеўскіх [Гл.: Janulaitis 1925: 216-219].

4 Каментар, праўда, адсутнічае, але "парыжскі" тэкст лёгка "пазнаецца".

53 заўважаных мадэрнізацый тэксту адзначым выкарыстанне літары й, хоць у выданні 1862 г. яна амаль не ўжывалася: толькі некалькі разоў гук [ў] друкар, не маючы адпаведных графем, перадаў адметным чынам - як й, ӥ ці $\boldsymbol{u}^{\prime}$. 
ў адным з тамоў Залатой калекцы беларускай літаратуры [2013: 562569, 838-839].

На жаль, нягледзячы на шэраг важных публікацый ${ }^{1}$, што з'явіліся ў друку за апошнія 50 гадоў, Гутарка... усё яшчэ застаецца на перыферыі літаратуразнаўчага даследавання. Галоўная прычына заключаецца ў тым, што ў Беларусі фактычна адсутнічаюць першакрыніцы - і самі выданні, і рукапісныя копіі твора. А гэта значыць, што навукоўцы не валодаюць самым неабходным.

Часткова праблему вырашыў доктар Тамаш Настульчык, супрацоўнік Даследніцкага цэнтра Польскай бібліяграфіi Эстрайхераў (Centrum Badawcze Bibliografii Polskiej Estreicherów), які здолеў сабраць выяўленыя раней, а таксама выявіць у розных архівах Літвы, Расеі, Польшчы і Беларусі дваццаць два дакументы з тэкстамі Гутаркі.... Вынікі сваіх даследаванняў навуковец апублікаваў у працы, а ў дадатку да яе змясціў фотакопіі ўсіх вядомых яму друкаваных выданняў і рукапісных копій беларускага ананімнага твора [Nastulczyk 2017].

Т. Настульчык грунтоўна разгледзеў гісторыю вывучэння Гутар$\kappa i . .$. беларускімі, польскімі, літоўскімі і расейскімі навукоўцамі. Ён унікліва прааналізаваў непаразуменні ды недакладнасці, якія маюцца ў публікацыях пра выданне твора, і прыйшоў да высновы, што амаль ніхто з даследнікаў (як выключэнне - 3. Тальвірская і Г. Кісялёў) не меў магчымасці параўнання друкаваных і рукапісных тэкстаў Гутаркі..., што твор характарызаваўся пераважна з ідэйна-палітычнага боку, але не звярталася ўвага на пытанні кнігазнаўчыя. (Недастаткова, на нашую думку, разгледжаны і тэксталагічны аспект). Гіпотэзы навукоўцаў і публіцыстаў адносна часу і месца выдання Гутаркі... Т. Настульчык аналізуе крытычна, выяўляе шматлікія хібы і нават, як ён называе, спекуляцы. Сваіх гіпотэз ён не прапануе, але схіляецца да таго, што "парыжскае" выданне рыхтаваў Браніслаў Шварцэ ў Беластоку, "пазнанскае" - асоба, якая не ведала беларускае мовы, а поўная адсутнасць інфармацыі пра “літаграфію" не дазваляе нават на вылучэнне гіпотэзаў.

Разглядае таксама навуковец праблему аўтарства Гутаркі.... Дакладней: канспектыўна аналізуе гіпотэзы фактычна ўсіх сваіх папярэднікаў. Аніводная з іх, на яго думку, не пацвярджаецца фактамі; яны заснаваныя ці то на перакананнях іх аўтараў, ці то на чутках, якія кружлялі ў пэўную эпоху і былі занатаваныя сучаснікамі.

Усіх тых, каго "вылучалі" на аўтарства папулярнага ў свой час твоpa, Т. Настульчык старанна фіксуе, а ў высновах сцвярджае, што спробы ідэнтыфікацыі паэта не прынеслі канчатковага адказу. Следам за польскім навукоўцам і мы пералічым усіх тых, хто называўся аўтарам Гутаркі...:

1. Кастусь Каліноўскі (Аскар Авейдэ ў матэрыялах следства) [1965: 99].

1 Самая значная з іх - у акадэмічнай Гісторыі беларускай літаратуры. Гл.: [Кісялёў 2007: 291-296]. 
2. Вінцэнт Дунін-Марцінкевіч (даносы жандарскіх агентаў і афіцэраў, Г. Кісялёў) [1961: 126-130].

3. Ян Героўскі (Аляксандар Ельскі ў матэрыялах да бібліяграфіі беларускае літаратуры) [AGAD 378, 1401, k. 395].

4. Вінцэсь Каратынскі (Я. Карскі [1922: III-3, 86-87], Р. Зямкевіч [1918 ], М. Гарэцкі [1920: с. 93-94 ], М. Канапацкі [1961] і інш.).

5. Уладзіслаў Сыракомля (3. Тальвірская) [1967: 59].

6. Браніслаў Шварцэ (Вольга Марозава) [1982: 49-50].

7. Вынік калектыўнай творчасці (Г. Кісялёў) [1961: 128].

8. Пераклад з польскае мовы (3. Тальвірская) [1967: 55-56].

9. Нехта 3 маладзейшых паэтаў 3 кола В. Дуніна-Марцінкевіча, У. Сыракомлі, Арцёма Вярыгі-Дарэўскага, В. Каратынскага (М. Хаўстовіч) [1999: 31].

На думку Т. Настульчыка,

пытанне аўтарства застаецца сёння нявырашаным з прычыны недастатковае колькасці крыніц. Наступны матэрыял могуць прынесці перш за ўсё новыя даследаванні <...>. Спробы спекулятыўнага множання ўяўных аўтараў альбо таксама суб'ектыўны пошук усялякіх супадзенняў варта трактаваць вельмі асцярожна, памятаючы, што мы маем справу з стылізаваным тэкстам, які захаваўся ў шматлікіх варыянтах з нявызначанай да канца храналогіяй [Nastulczyk 2017: 32].

Але найважнейшае, як ужо казалася, у публікацыі Т. Настульчыка, - гэта фотакопіi 22 варыянтаў Гутаркі.... У сувязі з тым, што кніга польскага навукоўца адсутнічае ў бібліятэках Беларусі, лічым патрэбным назваць і дэталёва ахарактарызаваць усе пададзеныя ў ёй дакументы.

1. HUTORKA STAROHO DZIEDA, nakładem A. Kurnatowskiego z Imbierowa pod Obornikami; czcionkami N. Kamieńskiego i Spółki w Poznaniu, 1861 r.

Г. зв. "пазнанскае" выданне. Кніжачка без вокладкі. 12 нумараваных старонак памерам 11 см у шырыню і 19 см у вышыню. Друк выразны, паўтлусты, высокае якасці.

Захаваўся адзін асобнікі; выяўлены на пачатку (?) 1960-х гадоў Г. Кісялёвым у Дзяржаўным архіве Расейскае Федэрацыі: фонд 109 [Tретье отделение Собственной Его Императорского Величества канцелярии], вопіс 36 [1 экспедиция. 1861 2.], справа 322 [О девице Марцынкевич в Минске, которая чрезмерно выказывала польский патриотизм] (Государственный архив Российской Федерацийㄹ, ГАРФ, ф. 109, оп. 36, 1 экспед. 1861, д.322). Справа змяшчае шэраг дакументаў пра дачку

${ }^{1}$ Іншы (?) асобнік выдання захоўваўся колісь у бібліятэцы Б. Эпімаха-Шыпілы [Гл.: Старонка вопісу бібліятэкі..., online]. Цікава, што для Biełarusskoj Chrestomatiji ён перапісваў Гутарку... з асобніка В. Мяніцкага.

2 у савецкі час: Цэнтральны дзяржаўны гістарычны архіў Кастрычніцкае рэвалюцыі ў Маскве. 
В. Дуніна-Марцінкевіча ${ }^{1}$. Яна была заведзеная 1 ліпеня 1861 года адначасна са справаю 323 [О пении гимнов в Минске, о панихиде Лелевелю и о книгопродавце Валицком]. Абедзве справы апавядаюць пра антыўрадавыя выступленні ў Мінску, пачынаючы ад сярэдзіны чэрвеня 1861 г. Калі і чаму “пазнанскае” выданне было далучана да справы 322, нам высветліць не ўдалося. Але вельмі верагодна, што жандары канфіскавалі яго падчас арыштаў і ператрусаў менавіта ў Мінску (ці Мінскай губерні) у 1861-1862 гг. У справе, якая налічвае 83 аркушы, Hutorka staroho dzieda змешчана як апошні дакумент (арк. 78-83v).

2. HUTARKA STAROHO DZIEDA, Paryż 1862 r. Lutego 27 (15) dnia.

Г. зв. "парыжскае" выданне. Кніжачка з вокладкай. 24 ненумараваныя старонкі памерам 7,5 см у вышыню і 9,5 см у шырыню. Друк не вельмі выразны, асобныя радкі ў катрэнах не выраўненыя па вертыкалі.

Асобнік захоўваецца ў Дзяржаўным гістарычным архіве Літвы ${ }^{2}$ ў фондзе 1248 [Временный полевой аудиториат при штабе командующего войсками Виленского военного округа (1863-1911)], вопіс 2 [Следственные дела участников восстания 1863 2.], справа 1497 [Дгло временнаго полеваго аудиторіата виленскаго военнаго округа о дворянинп Минской губерніи Алоизіи Витковскомъ], арк. 234-247v (Lietuvos valstybès istorijos archyvas, LVIA, f. 1248, ap. 2, b. 1497, l. 234-247v).

3. HUTARKA STAROHO DZIEDA, Paryż 1862 r. Lutego 27 (15) dnia.

Г. зв. “парыжскае" выданне. Кніжачка без вокладкі. 24 ненумараваныя старонкі памерам 7,5 см у вышыню і 9,5 см у шырыню. Друк не вельмі выразны, асобныя радкі ў катрэнах не выраўненыя па вертыкалі.

Асобнік захоўваецца ў Дзяржаўным гістарычным архіве Літвы ў фондзе 438 [Виленская следственная комиссия по политическим делам при Виленском генерал-губернаторе для разбора дел об участниках восстания 1863], вопіс 1, справа 290 [Справа пра ксяндза Дусьмінскага касцёла Гаплевіча і былога ксяндза віленскага Святаянскага касцёла Бішэўскага], арк. 16 (1-12v)³ (LVIA, f. 438, ap. 1, b. 290, l. 16 [1-12v]).

\footnotetext{
${ }^{1}$ Справу ўпершыню выкарыстаў Г. Кісялёў [1961: 119-138].

2 У савецкі час: Цэнтральны дзяржаўны гістарычны архіў Літоўскай ССР.

3 Да справы далучаны аркуш паперы, на якім напісана: “Разсказы Старика. Гутарка Старага Дзеда. Стихотворение въ родъ поэмы написанное Бълорусскимъ языкомъ латинскими буквами, напечатано въ Парижь въ 1862 г. февр 27 (15). По бумагъ и шрифту можно заключить, что стихотвореніе это напечатано въ Варшавъ, Вильно или въ какомъ нибудь другомъ городъ Западной Россіи. Содержаніе его возмутительное: въ немъ поносятся Русскіе власти и чиновники, представляются бедствія крестьянъ отъ Русс. чиновниковъ и проч. Начинается оно такъ: «Эй добрые люди, скажите мнъ // Что это на светъ будетъ. // Развъ Богъ не змилоется надъ нами // И дозволитъ пропасть подъ Москалями», т. е. подъ владельчествомъ Русскихъ" (арк. 12).
} 
4. HUTARKA STAROHO DZIEDA, Paryż 1862 r. Lutego 27 (15) dnia.

Г. зв. "парыжскае" выданне. Ненумараваныя старонкі памерам 7,5 см у вышыню і 9,5 см у шырыню. Друк не вельмі выразны, вялікая колькасць радкоў у катрэнах не выраўненая па вертыкалі. Тут знаходзяцца асобныя аркушы двух асобнікаў, сшытых разам: старонкі 1-12 і 19-24 аднаго ды 1-6 і 13-24 старонкі другога.

Захоўваюцца ў Нацыянальным гістарычным архіве Беларусі ў Гродне, фонд 1 [Канцелярия Гродненского губернатора], вопіс 22 [18511870], справа 1121 [Дело о обезоруживании местного населения, об освобождении от занимаемых должностей "неблагонадежных" лии, приближении к г. Гродно батареи и принятии других мер для борьбы с готовящимся восстанием. 14 апреля 1861 - 8 июля 1866 г.], арк. 401-418v (НГА РБ у Гродне, ф. 1, воп. 22, спр. 1121, арк. 401-418v).

5. Od staraho dzieda. Hutorka staraho Dzieda na Biełarusi, [без м. і г., літаграфія].

Кніжачка без вокладкі. 16 нумараваных старонак памерам 13 см у шырыню і 23,5 см у вышыню. Адбітак выразны, даволі высокай якасці.

Асобнік захоўваецца ў Дзяржаўным гістарычным архіве Літвы ў фондзе 1248 [Временный полевой аудиториат при штабе командующего войсками Виленского военного округа (1863-1911)], вопіс 2 [Следственные дела участников восстания 1863 2.], справа 1497 [Дгло временнаго полеваго аудиторіата Виленскаго военнаго округа о дворянинп Минской губерніи Алоизіи Витковскомъ], арк. 61-68v (LVIA, f. 1248, ap. 2, b. 1497, l. 61-68v).

Літаграфію ў архіве выявіла ў 1960-я гады (?) 3. Тальвірская. У сваім артыкуле яна згадала пра яе: "При обысках <...> обнаруживали <...> как печатные, так и литографированные и в рукописных копиях" [1967: 44], падаючы пры гэтым архіўны адрас - ЦГИА ЛитССР, ф. 1248, оп. 2, д. 1497, лл. 61-66 (насамрэч: 61-68v). Даследніца меркавала, што літаграфію выдала рэвалюцыйная арганізацыя Мінскай губерні [1967: 50]. Яна апісала выданне, якое "имеет как бы введение, которое называется Од стараго дзеда" [1967: 51], і працытавала ў перакладзе (не зусім дакладным!) асобныя ягоныя фрагменты. Звярнуўшы ўвагу, што гаворка ва ўступе ідзе пра замену “маскалямі” у беларускіх гутарках слова "ojczyzna" на "pańszyzna", яна прывязала датаванне публікацыі да падзей лета 1861 г., калі, як сцвярджае, назіралася “натравливание мужиков на помещиков" [1967: 52]. Апрача таго, 3. Тальвірская палічыла літаграфію (разам з г. зв. "кобрынскім" рукапісам) “наиболее ранними", бо "в текстах печатных имеются значительные дополнения о крестьянской реформе", а таксама і тое, што дадзены варыянт Гутаркі старога Дзеда створаны і выдадзены прыхільнікамі Людвіка Мераслаўскага, бо толькі тут (у перадапошняй страфе) згадваецца гэты дзеяч эміграцыі [1967: 58, 62]. 
На жаль, беларускія даследнікі не звярнулі ўвагі ні на тэкст, змешчаны ў літаграфіi, ні на архіўную справу, дзе яна (літаграфія) захавалася. У справе, праўда, няма звестак ні пра аўтара (-ў) твора, ні пра яго выдаўцоў, але з яе можна сёе-тое даведацца пра тых, хто распаўсюджваў розныя выданні Гутаркі..., а магчыма, і выдаваў іх. Прынамсі, варта больш пільна прыгледзецца да жыцця і дзейнасці былога студэнта Маскоўскага ўніверсітэта і актыўнага ўдзельніка рэвалюцыйных падзей на Міншчыне і Магілёўшчыне Ігната Пякарскага, які перадаваў праз Алаіза Віткоўскага “литографированные тетради, возмутительнаго содержанія" Альфрэду Ратынскаму, што жыў у маёнтку Краснае Вілейскага павета. Што цікава: і І. Пекарскі, і А. Ратынскі ўдзельнічалі ў паўстанні. Але нягледзячы на тое, што першы з іх быў пад судом у Магілёве, а другі “ушелъ въ шайку и пропалъ без вести”, у вядомых нам спісах паўстанцаў 1863-1864 гг. яны не значацца [Genealogia Polaków, online].

Т. Настульчык сцвярджае, што Г. Кісялёў ведаў архіўную справу, у якой захавалася літаграфія, але палічыў выданне за "рукапісны варыянт" [Nastulczyk 2017: 10]. Аднак гэта не так. Вядомы беларускі даследнік, безумоўна, ведаў гэтую справу, але не працаваў з ёю грунтоўна. Пра гэта сведчыць тое, што ён працытаваў у кнізе Сейбіты вечнага (уартыкуле В.Дунін-Марцінкевіч і паўстанне 1863 г., апублікаваным у пятым нумары часопіса "Полымя" за 1961 год, цытата адсутнічае) фрагмент прадмовы Od staraho dzieda паводле іншае справы, пазначаючы, што гэты тэкст захоўваецца ў ЦДГА ЛітССР, фонд 1248, вопіс 1 , спр. 22, а. 101. У дадзенай справе ідзе гаворка (сярод іншага) пра тое, як пры ператрусе 9 сакавіка 1863 г. у маёнтку Эміліі Бандзінскае Шыласяды, што ў Трокскім павеце, быў знойдзены аркуш, відаць, з літаграфаванага выдання Hutorki staraho dzieda na Biełarusi, уласна, прадмова да выдання - Od Staraho dzieda. Прычым, тэкст прадмовы займае дзве поўныя старонкі аркуша², а г. зн., што ў маёнтку Э. Бандзінскае захоўвалася картка з нейкага іншага, невядомага нам літаграфаванага выдання. Тое, што гэта літаграфія, не выклікае сумнення, хоць падчас ператрусу яна і названая рукапісам:

9 Марта произведенъ былъ у помьщицы Бондзинской обыскъ, причемъ въ занимаемыхъ ею комнатахъ найдено: 1). рукопись Слово стараго дъда, написанная для крьстьянъ съ цБлію возбудить въ нихъ враждебныя чувства къ правительству, которому приписывается по этой рукописи намереніе поссорить въ здешнемъ крае крьстьянъ съ помъщиками и, пользуясь этимъ, погубить объ стороны [LVIA 1248-1-22, l. 6].

1 Сёння - LVIA.

2 У вядомай нам літаграфіі прадмова займае першую старонку (24 радкі) і 7 радкоў на другой старонцы. У літаграфіi, знойдзенай у доме Э. Бандзінскае, на першай старонцы размешчаны 21 радок, а на другой - 22, г. зн., што выданні друкаваліся на паперы рознага фармату. 
Зусім верагодна, што ў маёнтак Шыласяды аркуш з літаграфіі трапіў выпадкова: у гэтым рэгіёне славянскага насельніцтва было няшмат. I нават сама гаспадыня маёнтка не зразумела, калі верыць сказанаму ёю падчас следства, сэнс твора: “найденное у нее возмутительное сочиненіе она получила отъ неизвестнаго крестьянина и сама не поняла его содержанія" [LVIA 1248-1-22, l. 164v].

Звернем яшчэ ўвагу на тое, што “літаграфія Э. Бандзінскае” не з'яўляецца дакладнаю копіяю прадмовы з вядомае "літаграфіі А. Віткоўскага-І. Пякарскага". Мы налічылі амаль два дзясяткі адрозненняў. Прычым, “літаграфія Э. Бандзінскае” больш “пісьменная” (асабліва гэта датычыць расстаноўкі знакаў прыпынку і ў кароткага), правільная з пункту гледжання мовы. Напрыклад, яўная апіска ў рукапіснай копіі літаграфіі з Бібліятэкі акадэміі навук Літвы імя Урублеўскіх "chachoczyс́ naruhajuczycia” у ёй адсутнічае: "chachoczyć naruhajuczysia”.

Цікава і тое, што ўсе вядомыя сёння тэксты прадмовы Od staraho dzieda з'яўляюцца копіямі “літаграфіi А. Віткоўскага-І. Пякарскага", а не “літаграфіі Э. Бандзінскае”. Мяркуем, што “літаграфія Э. Бандзінскае” (калі сапраўды існавала такая літаграфія, а не толькі аркуш-улётка прадмовы да выдання двух гутарак і малітвы Boże szto Polszcze...) магла быць тым выданнем (хутчэй: часткай выдання), з якога царская адміністрацыя Мінскай губерні зрабіла дзве транслітараваныя копіі.

6. Hutorka staroho dzieda, „Dziennik Literacki” (Lwów) 1861, nr 89 (8 listopada), s. 714-716.

Апрача тэксту твора ў газеце ў зносцы даецца кароткі моўны каментар.

\section{Od staroho dzieda. Hutorka staraho dzieda na Biełarusi.}

Г. зв. "рукапісная копія літаграфіі". Сшытак на 28 нумараваных старонак памерам 17 см у вышыню і 11 см у шырыню.

Тэксты твораў, на нашую думку, скапіраваныя з літаграфіі - назавём так - "А. Віткоўскага", але маюць шэраг адрозненняў. Пададзім важнейшыя: прапушчаныя словы, знакі прыпынку, а таксама не заўсёды паслядоўнае адлюстраванне акання. Захоўваецца ў Бібліятэцы акадэміі навук Літвы імя Урублеўскіх, ф. 22, спр. 2 [Дьло по донесенію Начальника Ковенской Губерніи, съ предоставленіемъ тетрадей возмутительнаго содержанія, представленныхъ однодвориемъ Гацевичемъ], арк. 3448 (LMAVB, f. 22, b. 2, l. 34-48). Выяўлены У. Абрамавічусам (з пазначэннем архіўнага адрасу справы наступным чынам: "в секретном деле Канцелярии Виленского военного губернатора, Бх 89, с. 11-26)” [Абрамавичюс 1949:80].

Дакументы справы сведчаць, што сшытак быў скрадзены ў падарожных адналдворцам Вікенціем Гацевічам у снежні 1861 г. у карчме Лупянка блізу Новалалександраўска [да 1836 г. называлася Езяросы, даўняе мястэчка гістарычнае Браслаўшчыны; пераіменаванае на загад Мікалая I у гонар сына Аляксандра. Сёння - Зарасай (літ.: Zarasai)]. 


\section{Hutarka staroho Dzieda.}

Г. зв. “лепельскі" рукапіс. Аркуш паперы памерам 33,5 см у вышыню і 22 см у шырыню, запісаны з абодвух бакоў.

Захоўваецца ў Дзяржаўным архіве Расейскае Федэрацыі ў фондзе 109 [Третье отделение Собственной Его Императорского Величества канцелярии], вопіс 36 [1 экспедиция. 1861 2.], у справе 303, ч. 6 [O политических беспорядках в Западных губерниях. По Витебской губернии], арк. 121-121v (ГАРФ, ф. 109, оп. 36, 1 экспед. 1861, д. 303, ч. 6, л. 121122v), якая была заведзена 29 сакавіка 1861 г. Hutarka staroho Dzieda была далучана да "отношенія"1 полацка-віцебскага архіепіскапа Васіля Лужынскага ад 15 мая 1862 г. обер-пракурору Сінода Аляксею Ахматаву, у якім паведамлялася, што твор шырокавядомы ў Лепельскім павеце. Рукапіс выявіў у 1960-я гады Г. Кісялёў, хоць адно толькі згадаў пра яго ў сваёй публікацыі ў часопісе “Полымя” (1961, № 5, с. 127).

\section{Hutoryka staroho dzieda 1861 r. z Kobrynia.}

Г. зв. "кобрынскі" рукапіс. Два аркушы паперы памерам 28,5 см у вышыню і 22,5 см у шырыню, запісаныя з абодвух бакоў. Угары першага аркуша дата: "13 cerwса".

Захоўваюцца ў Дзяржаўным гістарычным архіве Літвы ў фондзе 378 [Канцелярия Виленского, Ковенского и Гродненского генерал-губернатора. 1768-1915. Политический отдел. 1864], справа 106 [О дворянинп Радомской губерніи Опочинскаго упзда Константинп Лопатецкомъ], арк. 12-13v (LVIA, f. 378, PS. 1864, b. 106, l. 12-13v). Копію выявіў у 1960-я гады Г. Кісялёў [1963: 140].

\section{0. Гуторка старого Дзіеда.}

Г. зв. першая мінская транслітараваная копія літаграфіi. Сем аркушаў паперы памерам 31 см у вышыню і 19,5 см у шырыню; тэкст запісаны каліграфічным грамадзянскім пісьмом з абодвух бакоў.

Захоўваецца ў Дзяржаўным архіве Расейскае Федэрацыі ў Маскве ў фондзе 109 [Третье отделение Собственной Его Императорского Величества канцелярии], вопіс 36 [1 экспедыцыя. 1861 г.], у справе 322 [О девице Марцынкевич в Минске, которая чрезмерно выказывала польский патриотизм], арк. 16-22v (ГАРФ, ф.109, оп. 36, 1 экспед. 1861, д. 322, л. 16-22v).

Транслітараваная копія літаграфіi² (без празаічнага ўступу $\mathrm{Od}$ staraho dzieda) змешчана ў дадатку да рапарту (арк. 10-15) мінскага губернскага жандарскага штаб-афіцэра палкоўніка Б. Рэйхарта ад 17 лютага 1862 года, у якім даводзілася, што ў напісанні Гутаркі старога Дзеда на падставе падабенства з Ідыліяй можна падазраваць В. ДунінаМарцінкевіча:

\footnotetext{
1 Праваслаўныя святары (благочинные) мелі абавязак сачыць за ўчынкамі палякаў-католікаў і дасылаць рапарты архіепіскапу, які на аснове гэтых рапартаў пісаў “отношенія" обер-пракурору Сінода.

2 Мае шэраг адрозненняў ад вядомае літаграфіi.
} 
Вредна эта девица Марцинкевич здесь и не мешало бы ее удалить, а между тем высшее местное начальство дозволило ей заниматься обучением детей нежного возраста, и можно себе вообразить, что она им проповедует. От роду ей около 26 лет, характера дерзкого и решительного, а идеи унаследовала от отца. Этот мелкопоместный помещик Минского у. пишет и распространяет патриотические сочинения, недавно ездил в Варшаву, а возвратившись, отправился, с дозволения временного военного губернатора Минской губ., в губ. Ковенскую, Виленскую и Витебскую: цель этой поездки, как полагать надобно, - распространить революционные идеи, особенно в губ. Витебской. Между изданными им сочинениями одно на местном наречии под заглавием Селянка весьма сходно в слоге с представляемыми при сем в копии появившимися тут литографированными стихами и, наверное, принадлежащими ему же, дерзко противу правительства и возмущающие крестьян написаны собственно для простого народа их языком, которым Марцинкевич хорошо владеет [Революционный подъем... 1964: 542].

Інфармацыю пра рукапіс падае 3. Тальвірская [1967: 43].

\section{1. Гуторка старого Дзпда.}

Г.зв. другая мінская транслітараваная копія літаграфіi. Восем аркушаў паперы памерам 37 см у вышыню і 23 см у шырыню; тэкст запісаны каліграфічным грамадзянскім пісьмом з абодвух бакоў.

Захоўваецца ў Расейскім дзяржаўным гістарычным архіве ў Пецярбурзе ў фондзе 1282 [Канцелярия министра внутренних дел], вопіс 1 [1812-1917 г2.], справа 25 [Переписка с генерал-губернатором, военными и гражданскими губернаторами Западных губерний о принятии мер $\kappa$ прекращению <...> антиправительственных выступлений и пропаганды в этих губерниях], арк. 232-239v (Российский государственный исторический архив, РГИА, ф. 1282, оп. 1, д. 25, л. 232-239v).

Транслітараваная копія літаграфіі (без празаічнага ўступу Od staraho dzieda) зроблема, магчыма, з тае самае літаграфіi, што і папярэдняя, хоць прынцыпы транслітарацыі розныя. Копію заверыў мінскі віцэ-губернатар Аляксандар Лучынскі. Інфармацыю пра рукапіс падае 3. Тальвірская [1967: 43].

\section{Hutorka staraho dzieda.}

Г. зв. кракаўскі рукапіс. Чатыры аркушы паперы памерам 20,5 см у вышыню і 13 см у шырыню; тэкст запісаны з абодвух бакоў (адварот апошняга аркуша без тэксту).

Захоўваецца ${ }^{1}$ у Ягелонскай бібліятэцы, сігнатура 9288"II [Wiersze różne przesłane Józefowi Bohdanowi Zaleskiemu], k. 85-88 (Biblioteka Jagiel-

1 у складзе сшыта-склеенага збору рукапісных, друкаваных і літаграфаваных аркушаў паперы рознага фармату. Пераважна копіі твораў Уладзіслава Сыракомлі, Вінцэнта Поля, Севярына Гашчынскага, Юльяна Нямцэвіча, Юльяна Корсака (Wiersz na śmierć Dominika Moniuszki), Гераніма Кайсевіча, Нарцызы Жміхоўскае, Дэатымы; пераклад на польскую мову Слова пра паход Ігаравы; шэраг украінскамоўных твораў, а таксама народных песняў. Апрача Гутаркі старога 
lońska w Krakowie, BJ, sygn. 9288"I, k. 85-88). Дасланы ці перададзены невядомым Юзафу Багдану Залескаму (1802-1886).

\section{Hutorka staroho dzieda.}

Г. зв. уроцлаўскі рукапіс. Два аркушы паперы памерам 26,5 см у вышыню і 21 см у шырыню; тэкст запісаны з абодвух бакоў (адварот апошняга аркуша без тэксту).

Захоўваецца ў Бібліятэцы Нацыянальнага інстытута імя Асалінскіх, сігнатура 14708/III: Wiersze różne zebrane przez Marcelego Michała (ojca) i Stanisława Marcelego (syna) Nałęcz-Dobrowolskich, k. 133-135 (Biblioteka Zakładu Narodowego im. Ossolińskich we Wrocławiu, ZNiO, sygn. 14708/III, k. 133-135).

Hutorka staroho dzieda не перапісаная, а ўкладзеная ў “анталогію”, г. зн. аркушы рукапісу паходзяць, магчыма, нават з 1860-х гадоў. Звяртае на сябе ўвагу дата на доле трэцяе старонкі - "1861 r. 9 Маіа".

Рукапіс выявіў Т. Настульчык.

\section{Hutarka staroha dzieda.}

Рукапіс Б. Эпімаха-Шыпілы. Перапісаўшы у 1889 годзе Гутарку старога Дзеда паводле “парыжскага" выдання, Б. Эпімах-Шыпіла ўключыў яе ў рукапісную анталогію Biełarusskaja chrestamatyja.

Захоўваецца ў Беларускім дзяржаўным архіве-музеі літаратуры і мастацтва (БДАМЛіМ) у фондзе 66 [Бэндэ Лукаш Апанасавіч], вопіс 1, адзінка захавання 1256 [Б.І. Эпімах-Шыпіла. Беларуская хрэстаматыя. Аўтограф], арк. 3r-10r.

\section{Hutorka Staroha dzieda.}

Рукапіс А. Ельскага. Сшытак на дванаццаці старонках, папера памерам 17,5 см у вышыню і 11,5 см у шырыню (адварот апошняга аркуша без тэксту). На вокладцы рукою Аляксандра Ельскага: “Hutorka Staroha dzieda. 1862 r. była drukowana w Paryżu".

Захоўваецца ў Галоўным архіве даўніх актаў у Варшаве: фонд 378 [Archiwum Prozorów i Jelskich], № 140 1 [Materyały bibliograficzne z zakresu literatury białoruskiej zbierane przez Al. Jelskiego], арк. 184-194 (Archiwum Główne Akt Dawnych w Warszawie, AGAD, sygn. 378, nr 1411, k. 184-194).

Дзеда ў зборніку змешчаны гімн Boże, szto Polszy... (s. 68-69) - варыянт “парыжскага" выдання, але без апошняе страфы.

${ }^{1}$ Складаецца з трох частак (тамоў), усяго 440 старонак (t. I - 144 c., t. II - 74 c, t. III 222 с.). Аркушы рознага памеру з тэкстамі вершаваных твораў, лістоў і нататак сшыты-склеены ў тры сшыткі. Шмат якія тэксты датаваныя: самы ранні паходзіць 31846 г., найпазнейшы - 1950 г. Пераважная большасць твораў ананімная, але ёсць і вядомых аўтараў XIX стагоддзя: Адама Міцкевіча, Вінцэнта Поля, Зыгмунта Красінскага, Уладзіслава Сыракомлі, Аляксандра Пушкіна (фрагмент Яўгена Анегіна), а таксама шэраг украінскіх народных песняў (Oj w mesteczku Beresteczku). Даволі шмат дакументаў паходзіць з 1860-х гг. Храналагічны прынцып размяшчэння дакументаў складальнікамі не выкарыстоўваўся. 
16. Od staryha dzieda. Hutorka staroha dziada na Białorusi.

Рукапіс Беларускага музею ў Вільні. Тэкст занатаваны (з невялікімі зменамі) паводле літаграфіi (аднак адсутнічае Malitwa dzisiejszaja: Boże szto Polszcze...) напрыканцы XIX - у пачатку XX стагоддзя 1 ў зборніку польскіх, беларускіх, украінскіх і расейскіх вершаваных твораў і фальклорных тэкстаў (арыгінальная нумарацыя: с. 84-102). Выяўлены У. Абрамавічусам [1949: 80].

Захоўваецца ў Бібліятэцы акадэміі навук Літвы імя Урублеўскіх, фонд 21 [Vilniaus baltarusių fondas], справа 927, арк. 42r-51r (Lietuvos mokslų akademijos Vrublevskių biblioteka, LMAVB, f. 21, ap. 927, 1. 42r-51r).

\section{Hutorka staraho Dzieda na Biełarusi.}

Машынапіс Т. Урублеўскага. Дакумент на падставе рукапіснае копіі літаграфіі (гл. пазіцыю 7) з праўкамі Тадэвуша Урублеўскага (18581925), падрыхтаваны, на нашую думку, дзеля публікацыі ў зборніку Karo Archyvas. Гл.: A. Janulaitis, Spausdintieji ir nespausdintieji 1863-64 m. sukitimo raśtai [w:] Karo Archyvas, t. 1, Kaunas 1925, s. 216-219. Выяўлены У. Абрамавічусам [1949: 80].

Захоўваецца ў Бібліятэцы акадэміі навук Літвы імя Урублеўскіх, ф. 9, спр. 146, c. 1-12 (LMAVB, f. 9, b. 146, l. 1-12).

\section{Skažéće dóbryie luźi...}

Запіс Э. Кліха. Фрагмент (32 радкі) Гутаркі старога Дзеда, запісаны Эдвардам Кліхам на пачатку XX стагоддзя на Наваградчыне.

Надрукаваны Эдвардам Кліхам [1907:65-66].

19. Hutarka staroha dzieda 1863 hodzie było paustannie proci Maskaloŭ. Drahuny, dn. 16/VIII - 33 hodu.

Рукапіс Язэпа Малецкага. Фрагмент (38 радкоў) Hutorki staroha dzieda, запісаны Я. Малецкім у 1933 годзе на Дзісненшчыне.

Рукапіс захаваўся ў архіве этна-музыколага Антона Грыневіча ў папцы Сборы фольклорных материалов неизвестных авторов: Інстытут літоўскае літаратуры і фальклору, фонд Фальклорныя калекцыі Беларускага музею у Вільні (Vilniaus baltarusiq muziejaus tautosakos rinkiniai, LTR), сігнатура 7579 III-9, c. 7-7v (Lietuviq Literatures ir Tautosakos Institutes, LLTI, b. 7579-III-9, l. 7-7v). Выяўлены Вячаславам Мартысюком.

\section{0. Хутёръ Старого дпдя: Писалъ бълорусскій мужикъ.}

Расейскі пераклад гутаркі. Два аркушы паперы памерам 35 см у вышыню і 22 см у шырыню; тэкст з абодвух бакоў. Мае шматлікія праўкі, нанесеныя іншаю рукою.

Захоўваецца ў Дзяржаўным гістарычным архіве Літвы ў фондзе 439 [Архив музея графа Михаила Муравьева. 1830-1915], вопіс 1, справа 11 [Повстанческие документы периода восстания 1863 года], арк. 5455v (LVIA, f. 439, ap. 1, b. 11, l. 54-55v).

1 Уладас Абрамавічус датуе зборнік канцом XIX ст. [Абрамавичюс 1949: 80]. Т. Настульчык - другой паловай XIX ст. [Nastulczyk 2017: 12]. 
Рукапіс выявіла 3. Тальвірская, не звярнуўшы, аднак, увагі, што гэта пераклад твора на расейскую мову. Даследніца (хіба, правільна) залічыла яго да дакументаў, канфіскаваных паліцыяй падчас ператрусаў, хоць аніякія матэрыялы архіўнае справы ${ }^{1}$ гэта і не пацвярджаюць. T. Настульчык справядліва падкрэсліў, што "nie stanowi on prostej transkrypcji jednej ze znanych wersji białoruskich, lecz jest to raczej niezbyt udana próba adaptacji czy przekładu tekstu na język rosyjski (być może zabawa literacka, ciekawostka oparta na próbach stylizacji językowej?)" [2017: 13].

\section{1. [Mikalojus Akelaitis], Gromata Wylniaus Senelio. Pasaka Senelio} Surasze Wargdienelis isz Lietuwos.

Арыгінал літоўскага варыянта Гутаркі... (а таксама Ліста Старога з Вільні). Рукапіс на чатырнаццаці аркушах паперы памерам 18 см у вышыню і 11,5 см у шырыню; тэкст з абодвух бакоў.

Захоўваецца ў Дзяржаўным гістарычным архіве Літвы ў фондзе 378 [Канцелярия Виленского, Ковенского и Гродненского генерал-губернатора. 1768-1915. Политический отдел. 1861], справа 16, частка 2, арк. 5-18v (LVIA, f. 378, PS. 1861, b. 16-2, l. 5-18v). У дадзенай справе знаходзяцца матэрыялы следства пра спробу надрукаваць у Мемелі (Прусія, сёння: Клайпеда, Літва) Гутарку старога Дзеда ў перакладзе М. Акялайціса на літоўскую мову. Чатыры дакументы з гэтае справы надрукаваныя ў зборніку Революционный подъем в Литве и Белоруссии в 1861-1862 г2.: Материалы и документы (Москва 1964, с. 22-27, 30).

22. [Mikalojus Akelaitis], Gromata Wylniaus Senelio. Pasaka Senelio Surasze Wargdienelis isz Lietuwos.

Копія літоўскага варыянта Гутаркі... (а таксама Ліста Старога з Вільні). Рукапіс на чатырнаццаці аркушах паперы памерам 17 см у вышыню і 10,5 см у шырыню; тэкст з абодвух бакоў.

Захоўваецца ў Дзяржаўным архіве Расейскае Федэрацыі: фонд 109 [Третье отделение Собственной Его Императорского Величества канцелярии], вопіс 36 [1 экспедищия. 1861 2.], справа 165 [О предупреждении к провозу из-за границы в Западные губернии возмутительного воззвания, напечатанного в Мемеле на литовском языке в типографии Борха и о прикосновенных к этому делу студенте Буцкевиче, помещике Монтвилле, Катутисе и женщине Гищене], арк. 91-104v (ГАРФ, ф. 109, оп. 36, 1 экспед. 1861, д. 165, л. 91-104v).

Справа распачатая 22 мая 1861 года. У ёй - матэрыялы следства пра спробу надрукаваць у Мемелі Гутарку... у перакладзе М. Акялайціса на літоўскую мову. Два дакументы з гэтае справы надрукаваныя ў збор-

1 У дадзенай справе сабраны разнастайныя дакументы і матэрыялы (77 аркушаў), якія былі канфіскаваныя ў паўстанцаў. На жаль, не захавалася ніякіх сведчанняў пра іх уладальнікаў, пра тое, калі і пры якіх абставінах яны трапілі ў рукі жандараў ці паліцы. 
ніку Революционный подъем в Литве и Белоруссии в 1861-1862 г2.: Материалы и документы, Москва 1964, с. 21-22, 27-29.

3 дваццаці двух варыянтаў Гутаркі..., якія захаваліся і выяўленыя даследнікамі, найбольшую каштоўнасць дзеля тэксталагічных, крыніцазнаўчых і атрыбуцыйных даследаванняў маюць толькі дванаццаць $\left(1-13^{1}, 20\right)$. Бо пазнейшыя копіі ды вусныя ўзнаўленні канца XIX першае трэці XX стагоддзя могуць адно пасведчыць, што твор быў вядомы калекцыянерам ды навукоўцам², а таксама тое, што і праз некалькі дзесяцігоддзяў захоўваўся ў народнай памяці.

Перш за ўсё мы выключаем з нашага аналізу рукапісныя копіі Б. Эпімаха-Шыпілы, А. Ельскага, рукапіс Беларускага музею ў Вільні, машынапіс Т. Урублеўскага, а таксама запісы Э. Кліха і рукапіс Я. Малецкага. Бо яны ўзноўлены паводле друкаваных выданняў3; памылкі альбо свядомае перайначванне тэксту не можа "паспрыяць" справе даследавання гісторыі напісання твора. Укантэксце нашае працы не маюць важнага значэння і фалькларызаваныя пераказы Гутаркі... у XX ст.

Па-за межамі нашага даследавання, на жаль, застаецца і літоўскі пераклад твора. Наколькі нам вядома, апрача цалкам няўдалага тлумачэння на расейскую мову, выкананага на патрэбы следства і надрукаванага ў Зборніку дакументаў музея графа Мураўёва [Литовскія письма... 1906: 33-35], а таксама падрадковага перакладу 50 радкоў твора, змешчанага ў артыкуле 3. Тальвірскае [1967: 32], ні па-беларуску, ні парасейску Pasaka Senelio не друкавалася. Сёння патрэбны як пераклад літоўскага твора, так і параўнальна-тэксталагічны аналіз беларускага і літоўскага варыянтаў. Гэта можа дапамагчы ў вырашэнні атрыбуцыі Гутаркі.... А сёння відавочна толькі тое, што асноўны тэкст беларускае Гутаркі... ўзнік да сярэдзіны сакавіка 1861 г., а найбольш верагодна яшчэ ў 1860 г.

Варта таксама колькі слоў сказаць пра ўкраінскія вершаваныя пракламацыі часоў Паўстання. Прафесар Нацыянальнага педагагічнага ўніверсітэта імя М. Драгаманава Людміла Іванова сцвярджае, што было іх шмат: “У 1861-62 рр. це були такі відозви: Знайте, люди, для чого цар військо тримає, Хмара часів минулих і сучасних, Поради старого діда, До

1 Пазіцы 2-4 - гэта “парыжскае выданне Hutarki....

2 У Беларускім дзяржаўным архіве літаратуры і мастацтва [БДАЛіМ 66-1-993, с. 38] захоўваецца машынапісная копія Гутаркі..., а таксама копія гутаркі Ці знаеце, мае дзеці..., якія на падставе сваіх ранейшых запісаў выканаў у 1950-я гг. (датаванне архівістаў) Л. Бэндэ. Архіўны адрас адсутнічае, але пазнака “№ 232” на першай старонцы дазваляе меркаваць, што вядомы вульгарызатар карыстаўся матэрыяламі Канцылярыі міністра ўнутраных спраў [РГИА 1282-1-25]. Параўнанне тэксту Л. Бэндэ з г. зв. другой мінскай транслітараванай копіяй літаграфіі пацвярджае нашае дапушчэнне.

3 Копіі Б. Эпімаха-Шыпілы і А. Ельскага - паводле “парыжскага" выдання; рукапіс Беларускага музею ў Вільні і рукапіс Т. Урублеўскага - літаграфіі ці яе копій. 
козаків, які нині селяни, Голос Шевченка із Сибіру, Всім і кожному передаючи в волості, Польща наша нашим царством буде, Русинський народе, Рекрути" [Іванова 2013: 183]. Крыху ніжэй яна падае цытату з украінскага твора, на якую не можам не звярнуць увагі: “Крикнем всі в одні слова: нехай Польська буде знова, бо як станем поляками, будем рівні із панами" [Іванова 2013: 183]. Пры гэтым яна спасылаецца на apxiy̆ III аддзялення: “ДАРФ в Москві, фонд 109, I експ., оп. 1862, спр. 6265”. Тут, відаць, нейкая памылка: наўрад ці вершаваны тэкст, працытаваны даследніцаю, можа знаходзіцца ажно ў чатырох архіўных справах. Да таго ж, паводле Электронных вопісай ДАРФ у фондзе 109 (воп. 37 [1862]) маюцца толькі справы 63 [О беспорядках, допущенных в Киевском Кадетском Корпусе Св. Владимира] і 65 [По поводу распространившегося по всему Новороссийскому краю слуха о переводе из г. Одессы в г. Николаев Университета] [Электронные описи, online]. На жаль, мы не змаглі спраўдзіць інфармацыю Л. Івановае, ці сапраўды існаваў украінскі пераклад Гутаркі старога Дзеда? Аднак ведаем, што ўкраінскія творы, шмат у чым блізкія беларускім, сапраўды пашыраліся. Маем на ўвазе гутаркі Знайте, люде, для чого цар висько трымап і Hаступап туча: Туча прошедшых и настоящых времен, выяўленыя у сакавіку 1862 г. у в. Расошкі Уманскага павета [ГАРФ 109-37-228; ЦДІАК України 442-812-4, арк. 43-44, 37-42]. Гэта, вядома, арыгінальныя творы, але, на нашую думку, уплыў Гутаркі... адчуваецца. Пададзім некалькі фрагментаў [Фрем Запорожець 2013: 44, 47, 48, 49, 50, 51]:

\author{
А знањте ж, мыли браты, \\ Як прыйшлось до того, \\ От треба вам розказаты \\ Слова дида мого. <...> \\ Видтогди-то Украина \\ Голосыть почала, \\ Що проклята ж та годына, \\ Як Москва нас взяла. \\ Видтогди вже и паны намы \\ Владиты почалы, \\ Бо им на то цары самы \\ Позваляты сталы. \\ Дужчый став душыть слабшого, \\ А той ныжчых давыт, \\ Москаль все для взятку свого \\ Началныкив ставыт. <..> \\ За нас также паны хтилы \\ И свою кров ляты, \\ Но мы за то их ловылы \\ Ну ж в суд прыставляты. \\ Ляхы то нас хтят увольныты, \\ Не московскый цар, \\ 3 нымы то нам треба жыты, \\ Щоб знов не був свар. \\ Чумакы ж се трохы зналы,
}

Як в Севастополи Найбильш за то војовалы, Щобы из неволи Выпустыв цар Польщу, Лытву, Русь и Украину, А мы шлим за ных молытву Во всяку годыну. То все ляхы напросылы, Протерпившы много, Трыдцят лит в чужыни жылы Видцуравшысь свого. <..> Москаль все робыт лесткамы, Хоть ся пидсидањ, Побачыте, що зробыт з намы, Як нас загнуздањ. Бо вин завше хытрощамы Вси дила провадыть, Гирше з ным, як из ляхамы, Мужыкови зладыть. <..> А подати як станут браты 3 старого й $з$ малого, Тогди то будемо знаты Мылость цара свого. Акцыз на силь и вид водкы, Недоимок много, 
Оплат вид чумацькой ходкы -

А це все для чого? <...>

Знањте, як пип их стане

В церкви помынаты,

Хрестянын аж обивяне,

Докучыт стояты. <..>

Воны навет нашу виру

Зовсим изминылы.

Опысать то - жаль папыру,

Чого мы дожылы.

Служба Божа не набожна,

Попы сяки-таки,

С кого тилькы ино можна
Рвут, як кисть собаки, <..>

В висько там и паньски диты

Мусят поступаты,

Салдатом перш тра служыты,

Закым чын достаты.

А тут усе мужыкамы

Диры запыхают,

Обдырают податямы,

В рекруты прыймают.

Выбырайте тепер, люде,

А казкы не гудьте,

Як вам лутше жыты буде,

То так соби будьте.

Асабліва выразна пра тое, што ўкраінскі аўтар быў знаёмы з беларускамоўнымі творамі Паўстання, сведчаць наступныя радкі:

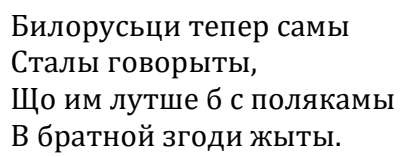

[Фрем Запорожець 2013: 47].

Магчыма, пад псеўданімам Фрем Запорожець хаваўся нехта з сябpoy̆ Ogółu, студэнт аднаго з расейскіх універсітэтаў. Менш праўдападобна, што аўтар украінскага твора выпадкова пазнаёміўся з літаграфіяй Hutorka staraho Dzieda na Biełarusi (менавіта з гэтым варыянтам, бо толькі тут акрэсліваецца ў пэўнай ступені ідэнтычнасць Дзеда). Пра аўтара і час напісання ўкраінскага твора можам меркаваць па словах спраўніка Уманскага павета:

По рассмотрении смысла стихов и наречия, на котором они писаны, ясно видно, во-первых, что они составлены личностью католического исповедания, слабо знающего малороссийское наречие, что доказывают слова, подчеркнутые мною в рукописи красными чернилами, и написаны с целью нарушить спокойствие простого народа, что сочинитель их, как бы для блага предлагая изводить (москалей) русских и соединиться с католическим населением; и во-вторых, что стихи эти написаны давно, или долгое время находились в употреблении, что доказывает измятость, неопрятность и загрязнивший вид рукописи [Фрем Запорожець 2013: 39].

Супаставіўшы дванаццаць варыянтаў твора, мы палічылі патрэбным падзяліць іх на пяць груп.

Да першае (А) групы мы адносім варыянты тэксту літаграфаванага выдання:

A 1 - літаграфія.

А 2 - рукапісная копія літаграфіi.

A 3a i A 3b - транслітараваныя копіі невядомай сёння літаграфіi A 3 - “першая мінская транслітараваная копія літаграфіi” і “другая мінская транслітараваная копія літаграфіi"). 
Тэксты гэтае групы ў цэлым адпавядаюць (з невялікімі выключэннямі) варыянтам іншых групаў. Прынамсі, В. Асноўная адметнасць групы A - наяўнасць страфы, у якой просьба "правільна" адказаць на пытанне "рэферэндума" дапаўняецца заклікам далучыцца да Людвіка Мераслаўскага з жаўнерамі, г. зн. да паўстання. Больш значныя адрозненні маюцца з варыянтамі групаў C, D i E.

Ёсць падставы лічыць, што гэтая рэдакцыя твора - самы ранні, першасны варыянт Гутаркі старога Дзеда.

У асобную групу (B) мы палічылі патрэбным аднесці два рукапісы, якія хоць і даволі блізкія да групы А, але ў іх адсутнічае характэрная страфа, у якой згадваецца Л. Мераслаўскі1.

1. В 1 - "кобрынскі" рукапіс.

2. В 2 - “лепельскі" рукапіс гутаркі (з “донесенія" В. Лужынскага).

Трэцюю (C) групу складаюць наступныя друкаваныя і рукапісныя варыянты:

1. С 1 - “пазнанскае" выданне.

2. C 2 - публікацыя ў львоўскай газеце "Dziennik Literacki”.

3. C 3 - "уроцлаўскі" рукапіс (з "анталогіi” Налэнч-Дабравольскіх).

4. С 4 - "кракаўскі" рукапіс (са збораў Ю.Б. Залескага).

Гэтыя варыянты Гутаркі..., апрача таго, што з'явіліся у друку у 1861 г., маюць характэрныя пазнакі-даты: у “анталогіi” Налэнч-Дабравольскіх - "1861 r. 9 Маіа". Асноўнае, што вылучае тэксты гэтае групы ад іншых, - гэта наяўнасць строф, у якіх ідзе гаворка пра ўяўны "рэферэндум" і просьба пакінуць піць гарэлку, каб "rozumu nie zduryci", як давядзецца выбіраць сабе "dolu”. Уласна, дзеля гэтага і пісалася Гутарка старога Дзеда. Важнае таксама тое, што ва ўсіх іх маюцца "дадаткі", якія відавочна былі дапісаныя пасля абнародавання царскага маніфеста ад 19 лютага 1861 года.

Чацвёртая група (D) - гэта расейскі пераклад твора - Хутёрь Cmaрого дъдя. Писалъ бълорусскій мужикъ. Адпавядаючы ў асноўным “пазнанскаму" выданню, дадзены варыянт асобнымі строфамі збліжаецца 3 “парыжскім" (гаворка пра тыя пяць строф, якія вылучаюць гэтае друкаванае выданне). Больш за тое: расейскі пераклад мае дзве страфы, якія адсутнічаюць ва ўсіх іншых вядомых сёння выданнях і рукапісах, але выдатна дапаўняюць згаданыя вышэй пяць строф “парыжскага" выдання. Калі дапусціць, што пераклад зроблены з пэўнага беларускага арыгіналу, то можна думаць, што існаваў яшчэ адзін варыянт твора.

Да апошняе, пятае (E) групы мы аднеслі “парыжскае" выданне. Асноўная адметнасць - скасаваныя ў двух месцах згадкі пра "рэферэндум", а таксама наяўнасць пяці строф, у якіх ідзе гаворка пра тое,

1 Калі варыянты групы А паходзяць ад рукапісу, які мог быць аўтарскім ці блізкім да аўтарскага і адно "сапсаваныя" страфой, дзе згадваецца Л. Мераслаўскі, то варыянты групы В узноўленыя "на слых" паводле гэткага ж самага (падобнага) рукапісу. 
што вольнасць сялянам жадалі даць “добрыя паны”, а вымусілі маскаля гэта зрабіць “пранцузы” - пераможцы крымскае вайны. Тэкст, відавочна, перапрацаваны пасля апублікавання рэформы 19 лютага 1861 года.

Схематычна гэта можна падаць наступным чынам. ([Рукапісы] A, B, C, D i E - гэта невядомыя сёння копіі пратографа.).

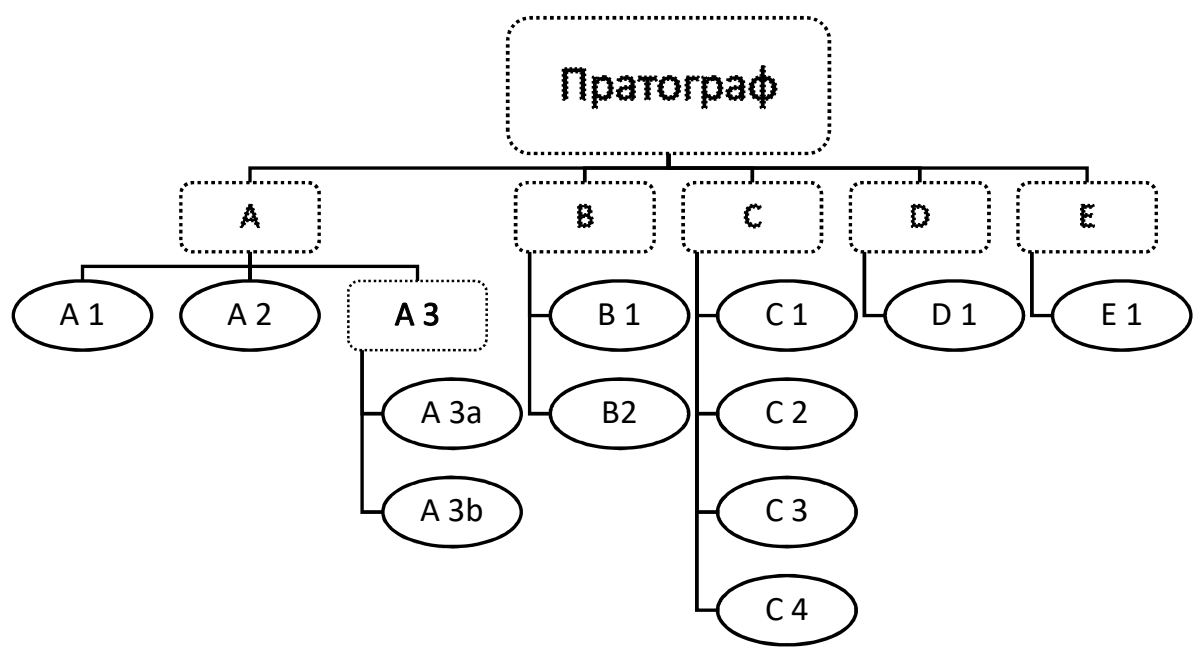

На нашую думку, у 1860 - пачатку 1861 года на аснове першаснага тэксту Гутаркі... (відаць, не пратографа, а пэўнае копіi) рыхтавалася літаграфаванае выданне твора, якое мы аднеслі да групы А. Яшчэ 3. Тальвірская сцвярджала, што літаграфія і “кобрынскі” спіс - гэта найбольш раннія варыянты беларускага твора. I аргументавала гэта тым, што яны найбольш адпавядаюць літоўскаму Pasaka Senetio Surasze Wargdienelis isz Lietuwos [1967: 52]. Пагаджаемся з дадзенай думкай. Не пярэчыць гэтаму і наяўнасць у літаграфіі страфы ${ }^{1}$ з заклікам далучыцца да жаўнераў Л. Мераслаўскага, г. зн. да паўстання, што ў пэўнай ступені парушае лад твора, скіраванага на "падрыхтоўку" сялян да "рэферэндума". (Афіцэрская школа Л. Мераслаўскага дзейнічала з 1859 года і рыхтавала яна, вядома, не агітатараў рэферэндума, а менавіта кіраўнікоў паўстанцкіх аддзелаў). 3. Тальвірская справядліва звярнула ўвагу, што ў "текстах печатных" маюцца "значительные дополнения о крестьянской реформе"; г. зн. узніклі яны пасля таго, як царскі маніфест ад 19 лютага 1861 года быў абнародаваны.

А вось у літаграфіi, а таксама ў тэкстах групы B і асобных тэкстах групы $\mathbf{C}^{2}$ мы не знаходзім радкоў, у якіх ішла б гаворка пра сялянскую рэформу 1861 года: тут адназначна сцвярджаецца: маскалі хочуць, “Kab

1 Яна магла быць дададзена падчас падрыхтоўкі літаграфіі да друку.

2 у шасці згаданых намі строфах “пазнанскага” выдання і ў анталогіі Налэнч-Дабравольскіх можна бачыць сялянскую рэформу як факт рэчаіснасці, што ўжо адбыўся: "Patul Maskala prasili, // Pakul nas nie|uwalnili". 
nas pany piłnowali", г. зн. пра аніякае скасаванне паншчыны аўтар (ці аўтары) яшчэ не чулі.

Усё гэта можа быць сведчаннем таго, што Гутарка... ўзнікла напярэдадні рэформы 19 лютага 1861 года і адна з першых рэдакцый твора зафіксаваная ў літаграфіi.

Сёння вядомы чатыры варыянты гэтае рэдакцыі: сама літаграфія (LVIA, f. 1248, ap. 2, b. 1497), рукапіс (LMAVB, f. 22, b. 2), які - вельмі верагодна - з'яўляецца копіяй літаграфіi, а таксама "кірылічная" транслітарацыя (у двух варыянтах) блізкага (але не ідэнтычнага!) да літаграфіi спісу твора (ці - хутчэй - іншай літаграфіi) (Рукапіс ГАРФ, ф. 109, оп. 36: 1 экспед., 1861 г., д. 322; РГИА, ф. 1282, оп. 1, д. 25).

Увогуле, для гэтае групы тэкстаў характэрна больш-менш паслядоўнае адлюстраванне на пісьме акання. Гэта найбольш поўна выяўляецца ў самой літаграфіi: od staraho, sabie, mahiłach, patreba, Palak, Maskal, dabra і інш. (але: blokotu, Ojczyzna, hutorki, po, pomochczy, toho і інш.). У рукапісе аканне перадаецца радзей. Тое самае можна сказаць і пра транслітараваныя тэксты: праўда, тут на адлюстраванне акання, магчыма, уплывала расейская мова пісараў. Транслітарацыі, дарэчы, зробленыя паводле аднаго і таго ж асобніка літаграфіі, але рознымі людзьмі: копія жандарскага палкоўніка Б. Рэйхарта выканана малавопытным пісарам: спалучэнне $d z i e-$ ён часта перадаваў як дзіе-, -сca як -цьця ці цься, -nаје як - наіе, й яе въ ці як $у$. Другая транслітараваная копія, прызначаная для канцылярыі міністра ўнутраных спраў і завераная мінскім віцэ-губернатарам А. Лучынскім ды прыгатаваная - вельмі верагодна! - на аснове папярэдняе, крыху па-іншаму перадае названыя спалучэнні: dzie- як дзъ-, -сcа як -цца, -naje як -наіе, й яе въ і як $y$, хоць гэта паслядоўна не вытрымліваецца і пісар часта паўтарае тое самае напісанне, што было ў зыходнай копіі. Варта было памыліцца "транслятару” палкоўніка Б. Рэйхарта, як тое самае паўтараў ${ }^{1}$ пісар віцэ-губернатара А. Лучынскага: гл., напрыклад, перастаўленыя радкі ў страфе "И|пранцузъ якъ робиу згоду" альбо памылковае напісанне шолдзы (замест szoldry).

Сцверджанне палкоўніка Б. Рэйхарта, што копія прыгатаваная паводле літаграфіі, выклікае пэўныя пытанні: 1. Чаму ў транслітараваным тэксце адсутнічае празаічны ўступ Od staraho dzieda?; 2. Чаму назва твора падаецца недакладна (замест Hutorka staraho Dzieda na Biełarusi Гуторка старого Дзъда)?; 3. Чаму гутарка Czy znajecie, mai dzieci падпісана Dzied, хоць у вядомай літаграфіi, а таксама ў рукапісе такога подпісу няма.

Маем падставы меркаваць, што мінскія жандары мелі ў сваім распараджэнні ці то нейкую іншую літаграфію (не тую, што захоўваецца y̆ LVIA, f. 1248, ap. 2, b. 1497), ці то пісар недакладна скапіраваў (транс-

1 Магчыма, аднак, што так было ў літаграфіі, якою карысталіся пісары. 
літараваў) яе. Наступныя прыклады могуць пацвердзіць, што дзеля транслітарацыі пісары мелі адрозны варыянт літаграфіі:

$\quad$ Лiтаграфія
Chacieŭ Palak dać
pamahaci
zwajewaći
znajeć
nazywajeć
Bucim dla takoj pryczyny
Nasić boty, strycca, bryci -
Choć nie majesz czym prażyci
Abdzierajuć i katujuć
Akcyzju pastanowili
wybiwacca
Kažnomu
Czy być ŭżo z Maskalami,
Czy znowu žyć z Palakami?
Kažin
kažnaho
U dwor im akzekucyiu stawiuć
szwydczej

\author{
Другая мінская транслітараваная \\ копія \\ Палякъ хоцЊвъ даць \\ памагаць \\ зваеваць \\ знае \\ называе \\ Бадца для такой причины \\ Насиць боты, стрыцца брыцца \\ Хоць ніе маешъ чимъ прожицца \\ Абдзираюць и катуюць \\ Акцизавъ пастановили \\ выбирацця \\ Каждому \\ Чи жиць ужо зъ маскалями \\ Чи зноу жиць зъ паляками \\ Коженъ \\ каждаго \\ У|дворъ имъ акзекуціи ставяць \\ бардзіей
}

Тагачасная памнажальная тэхніка дазваляла ўносіць праўкі. Магчыма, заўважыўшы ў адбітках памылкі і недакладнасці, выдаўцы паправілі надпіс на камені, а таксама дадалі невялікі празаічны ўступ.

Вядома, не ўсе памылкі ўдалося паправіць: напрыклад, ва ўсіх вядомых варыянтах, звязаных 3 літаграфіяй, сустракаем слова lichota (лихота). Пісары дакладна транслітаравалі яго, хоць у арыгінале, відавочна, павінна было быць lichoha: невыразна напісаная літара $h$ увяла ў зман перапісвальніка і рукапіснае копіі літаграфіi (A 2), і транслітараваных яе копій.

Звернем увагу яшчэ на адну лексічную асаблівасць аналізаваных намі тэкстаў - ужыванне слова taj/tay/maŭ. Яно шматразова сустракаецца ў літаграфіi, у рукапісе і транслітарацыях. Праўда, уласна ў $\mathrm{Hu-}$ torcy staraho dzieda na Biełarusi толькі двойчы ("Tay lichota nauczaje", "Tay i Niemcoŭ zwajawali"). Затое ў невялічкай прадмове да выдання яно ўжыта тройчы, а ў гутарцы Czy znajecie, mai dzieci ажно дзесяць разоў. Ці азначае гэта, што дадзеныя тэксты належаць аўтару-выдаўцу літаграфіi, які апрача таго, што ўключыў у выданне свае тэксты, адметнасцю свае гаворкі ${ }^{1 ~ “ п а з н а ч ы у ̆ ” ~ н а в а т ~ H u t o r k u ~ s t a r a h o ~ d z i e d a ~ n a ~ B i e ł a r u s i ? ~}$

I ўжо зусім складаную для вырашэння праблему ўяўляе ўжыванне слова taj у “пазнанскім" выданні твора (“Тај lichoho nauczaje”). Наўрад ці адбылося гэта выпадкова: хутчэй за ўсё “паходзіць” гэтае слова з літаграфіi (ці копіі, з якой выконвалася літаграфія) і можа сведчыць пра залежнасць “пазнанскага" выдання ад літаграфіі (ці пратографа літагра-

1 Відавочна, паходзіў з паўднёвых рэгіёнаў Беларусі альбо ведаў украінскую мову. 
фіi). Тым самым маем яшчэ адно пацвярджэнне першаснасці групы тэкстаў, якую мы назвалі А.

Гутарка... была напісаная сілабічным 8-складовікам з парнай жаночай рыфмоўкай. Прычым 8-складовік вытрыманы дасканала. У літаграфаваным выданні мы выявілі толькі 8 выпадкаў, калі замест 8-складовіка з'яўляюцца 7-складовікі (2), 9-складовікі (5) ці 10-складовік (1).

Варта спыніцца на кожным выпадку “парушэння" сілабічнае сістэмы, каб упэўніцца, што з'явіліся яны праз памылкі ці рэдагаванне перапісвальніка, што яны не аўтарскія.

1.У радку Czynoŭniki jaho zbytkujuć слова jaho маецца толькі ў варыянтах групы А. У іншых групах ужываецца альбо иsie (все), альбо йsio. I хоць не заўсёды пазначаецца, што й гэта зычны, але відавочна не можа быць гаворкі пра ўтварэнне дадзеным гукам складу.

2. Памыліўся перапісвальнік, калі ў радку Lepsz w Boha paprasicie падаў прыназоўнік $u$ як $w$. Ва ўсіх іншых варыянтах падобнае памылкі няма.

3. Магчыма, памылкова ў варыянтах групы А запісана слова zdausia ў радку Pakul Prancuz nie zdausia, бо ва ўсіх іншых рэдакцыях твора ўжываецца слова paddaŭsia.

4. Варыянт nie zastupiŭsia ў радку Za Maskala nie zastupiŭsia сустракаецца ў большасці варыянтах Гутаркі..., аднак ужытае ў А 3a, A 3b, B 1, C 2, C 3 слова ustupiŭsia паказвае, што колькасць складоў тут адпавядае аўтарскаму 8-складовіку ${ }^{1}$.

5. Колькасць складоў у радку Jak ich u Sybir wałaczyli змяншаецца да васьмі ў большасці рэдакцый Гутаркі... дзякуючы замене прыназоўніка $u$ на й. (Тут магчыма таксама, што гук [i] “ператвараецца” ў $j$ ).

6. Падобнае назіраем і ў радку Jak usiu szlachtu kasawali: слова usiu ў асобных варыянтах замяняецца на йsiu ці wsiu.

7. Радок $U$ dwor im akzekucyiu stawiuć з “дадатковай” колькасцю складоў паўтараецца амаль ва ўсіх рэдакцыях твора. Аднак C 1 і C 2 захавалі “правільную” форму: Agzekuciju u dwor stawiać.

8. Таксама і ў радку Z Maskalami dabra nie budzie праблема лішняга складу вырашаецца дзякуючы іншым, апрача А, групам рэдакцый Гутаркі...: Z Maskalom dabra nie budzie.

Дзеля захавання рытмічнага малюнку твора аўтар карыстаўся разнастайнымі прыёмамі. Вельмі часта ён ужывае сінярэзу: прыназоўнік $\boldsymbol{u}$ (зрэдку нават $\boldsymbol{u}$ на пачатку слова) пасля зычнага ператвараецца ў $\breve{\boldsymbol{u}}(\boldsymbol{w})$ : Da zaraz ŭ kości ujeusia; Ŭ aboz wazić usio zboże; Jedź ú kałodce da pryjomu; To naylepszych w turmu ciahnie; Jak Prancuz paszoŭ ŭ niewolu; Tady Maskal znoŭ wziaŭ wolu; Bo Niemiec w chytrość uszyŭsia. Але гэта не заўсёды ад-

1 У С 1 рэдактар дзеля захавання 8-складовіка нават пайшоў на змену сэнсу выказвання: Za Maskala zastupiŭsia. 
люстравана на пісьме, бо аўтарскую літару й перапісвальнікі выкарыстоўвалі дастаткова адвольна 1 .

Пэўную цікавасць выклікае выкарыстанне аўтарам дзеясловаў з інфінітыўным суфіксам -ci дзеля ўтварэння формаў простага будучага часу. На нашую думку, гэта адметны аўтарскі сродак захавання жаночае рыфмоўкі і адначасна 8-складовіка. Характэрна, што ён паслядоўна ўжываецца ў ранніх рэдакцыях твора (A 1, А 2, А 3a, A 3b, В 1, С 1, C 2, C 3 і С 4), а вось у варыянтах В 2 і Е 1 захаваліся толькі адзінкавыя выпадкі ўжывання дзеясловаў з суфіксам -ci.

Дасканалы 8-складовік прэзентуе “пазнанскае” выданне Hutorki... Нешматлікія адхіленні тлумачацца памылкамі набору.

Два рукапісы - мы назвалі іх дзеля зручнасці “кобрынскі” і “лепельскі" - мы вылучаем у асобную групу В.

“Кобрынскі" рукапіс створаны на падставе копіі пратографу, якая не мела шасці адметных строф “пазнанскага" выдання, а таксама страфы "Dziennika Literackiego", якая адсутнічае ў большасці варыянтаў. Матэрыялы справы, у якой захаваўся "кобрынскі" рукапіс, сведчаць, што перапісвальнікам Hutoryki staroho dzieda быy̆ арыштаваны ў студзені 1864 г. ураджэнец Апочынскага (Оросzno) павета Радомскае губерні пяцідзесяцігадовы Канстанцін Лапатэцкі, які у 1862-1863 гг. жыў у вёсцы Аляксоты Марыямпальскага павета. Абвіняўся ён "въ сношеніяхъ съ мятежниками”, “въ сочувствіи къ польскому возстанію, найденными у него при обыскъ стихами на польскомъ языкъ революционнаго содержанія и пояса съ польскимъ орломъ и погоней" [LVIA 378-106, l. 1]. (У іншым дакуменце справы Hutoryka..., а таксама польскамоўныя вершаваныя тэксты названыя "революціонными на польскомъ деолекть бумагами" [LVIA 378-106, l. 6]). Сам жа абвінавачаны тлумачыў следчай камісіі, што "стихи списаны имъ безъ всякаго умысла съ печатной книги 1773 года, пропущенной тогдашней цензурою; что поясъ носилъ отъ болъзни, но когда узналъ, что бывшіе на немъ знаки запрещены, бросилъ его" [LVIA 378-106, l. 35 v]. Параўнанне почырку Hutoryki... і тэкстаў, напісаных К. Лапатэцкім, сведчыць, што беларускамоўны твор скапіраваны ўраджэнцам Радомскае губерні. Вядома, не з "печатной книги 1773 года". Але адкуль? Адказаць адназначна на гэта пытанне не ўяўляецца магчымым. Магчыма, існаваў рукапісны варыянт Гутаркі... на заходнепалескай (кобрынскай) гаворцы, але жыхар Радомскае губерні не змог перадаць ейных фанетычных, марфалагічных і інш. асаблівасцяў. А валоданне (у нязначнай ступені,

13 дванаццаці тэкстаў, якія мы разглядаем, толькі ў сямі ўжываецца літара й. Найбольш часта - у рукапіснай копіі літаграфіi (77 разоў); ва "уроцлаўскім" спісе - 69; у самой літаграфіі - 68; у “пазнанскім" выданні - 63; у “кракаўскім" спісе - 61 (але тут гук [ў] яшчэ 12 разоў перададзены літараю $\boldsymbol{w}$. У “парыжскім” выданні і ў газеце "Dziennik Literacki” (відавочна з-за адсутнасці адмысловага знака) дзеля абазначэння $\check{y}$ нескладовага толькі спарадычна выкарыстоўваліся дыякрытычныя знакі $\boldsymbol{u}^{\prime}, \ddot{\boldsymbol{u}} ц і$ й. 
заўважым) расейскаю моваю, прывяло да таго, што ў “кобрынскім” рукапісе мы маем значна большую колькасць русіфікаваных лексемаў беларускае мовы, чым ва ўсіх іншых варыянтах твора.

Стан захаванасці (забруджанні і пацёртасці) гэтага рукапісу можа быць сведчаннем таго, што Hutoryku... працяглы час выкарыстоўвалі ў агітацыйных мэтах. І рабіў гэта К. Лапатэцкі, які - як высветліла следства - нібыта ў пошуках службы цэлы год раз'язджаў па Ковенскай і Віленскай губернях.

Дадзены рукапіс - гэта выкананая паспешліва ${ }^{1}$ копія твора са шматлікімі памылкамі (звяртае на сябе ўвагу злітнае і раздзельнае напісанне слоў, непаслядоўнае ўжыванне літараў $\boldsymbol{c}$ і $\boldsymbol{c}$, выкарыстанне польскіх графемаў $\boldsymbol{q}$ і $\boldsymbol{e}$ ). Пацвярджэннем таго, што кобрынскі рукапіс належыць да ранніх спісаў Гутаркі... можа быць радок "Za cto|ž my razom wojowali". Падобнае назіраем у А 1, A 2, A 3a, A 3b, C 4, В 2, у той час як у пазнейшых варыянтах чытаe "Za szto|ż jeny wajawali?" (C 1, C 2, C 3, E 1) ${ }^{2}$. Відавочна, варыянты C 4, В 1 і В 2 узніклі пасля таго, як свет убачыла літаграфаванае выданне (А 1), г. зн. не пазней вясны 1861 года.

“Лепельскі" рукапіс - гэта, магчыма, адзіны варыянт, які быў узноўлены па памяці. На карысць дадзенае гіпотэзы можа быць і значна меншая колькасць занатаваных радкоў (прапушчаная ледзь не цалкам “гістарычная частка" твора - дзевяць з чатырнаццаці катрэнаў3), і адсутнасць літары й (замест яе $\boldsymbol{u}$ ці $\boldsymbol{w}$ ), і скрэсленні ды выпраўленні (ukośé u iewsia - zaraz pa swaimu wziawsia; Biedny - Uiszow; nazad - razam; duraćmuciać - uczuć; Niechaj sabie Pany prosiać // Jm Exekuciu stawiuć) ${ }^{4}$, i шэраг словазлучэнняў, які не сустракаюцца ў іншых варыянтах (Boh tak radziu z nami; Maskali Palaka prahnali; pryniaw swajho hora; nia moh im pamahaci; To i druhich nie nauczaje; nay lepszych $w$ turmu ciahnie; Zakaonnami nas karbuiuć // Tłumiać kraduć zabieraiuć; szlachtaw z mużykami; Sam na czużbinie niaeboże; znow paszow narod hłumić; Choć duraki wymyślaiuć).

Характэрная асаблівасць дадзенае копіі - паслядоўнае адлюстраванне акання. Фактычна гэта адзіны рукапіс з групаў B і C, дзе выяўляецца вышэйназваная з'ява, якая дамінуе ў варыянтах групаў $\mathbf{A}$ і $\mathbf{E}$.

Тэксты групы C наўрад ці атрымалі шырокае распаўсюджванне ў краі. Аднак трапіўшы за граніцу, яны былі апублікаваныя, а рукапісы захаваліся ў прыватных архівах. Заўважым, што аніводзін з іх не з'яў-

1 Як прыклад паспешлівасці можам падаць радок “Z Polakami to bywało”, які з’явіўся замест чацвёртага радка папярэдняй страфы, пасля быў выкраслены, запісаны патрэбны радок, а пасля зноў паўтораны ўжо на належным месцы.

2 У расейскамоўным варыянце - "паны воевали".

3 Праўда, гэта магло быць зроблена адмыслова: перапісвальнік-кампілятар палічыў, што сяляне не зразумеюць.

4 Заўважым, што асобныя выпраўленні з'явіліся на месцы першаснага правільнага (верыфікуюцца іншымі варыянтамі твора) занатавання. 
ляецца літаральнай копіяй іншага. Адрозніваюцца яны і аб'ёмам, і моўнымі асаблівасцямі. Найперш пра аб’ём.

\begin{tabular}{|l|c|c|c|c|}
\hline & $\begin{array}{c}\text { "уроцлаўскі" } \\
\text { рукапіс }\end{array}$ & $\begin{array}{c}\text { "пазнанскае" } \\
\text { выданне }\end{array}$ & $\begin{array}{c}\text { "Dziennik } \\
\text { Literacki" }\end{array}$ & $\begin{array}{c}\text { "кракаўскі" } \\
\text { рукапіс }\end{array}$ \\
\hline $\begin{array}{l}\text { Колькасць } \\
\text { строфаў1 }\end{array}$ & 60 & 59 & 54 & 53 \\
\hline $\begin{array}{l}\text { Колькасць } \\
\text { радкоў }\end{array}$ & 240 & 236 & 216 & 211 \\
\hline
\end{tabular}

Першае знаёмства з "уроцлаўскім" рукапісам наводзіла на думку, што нехта - Марцэлі Міхал Налэнч-Дабравольскі (1829-1880) ці ягоны сын Марцэлі Станіслаў Міхал Налэнч-Дабравольскі (1876-1959) - перапісаў Гутарку... з “пазнанскага" выдання. Але больш уважліва прыгледзеўшыся да аркушаў у "анталогіi", мусім сцвердзіць: тэкст "уроцлаўскага" рукапісу мае на адну страфу (“Tam łob holać i musztrujuć...") больш, чым “пазнанскае” выданне. Якраз тую, дванаццатую страфу твоpa, якая была вядома раней толькі па публікацыі ў "Dzienniku Literackim". Вядома, можна дапусціць, што невядомы перапісвальнік, маючы і “пазнанскае” выданне, і патрэбны нумар львоўскай газеты, скампанаваў тэкст паводле ix. У выніку ў ягонай копіі аказалася і вышэйназваная страфа з "Dziennika Literackiego", і шэсць строфаў з "пазнанскага" выдання, якія больш нідзе не сустракаюцца ("Da uże pany dla narodu // Zdaŭna chaciać dać swobodu..."). Не выключаем гэтага. Праўда, вельмі цяжка ўявіць аматара (не навукоўца!) прыгожага пісьменства за такою працаю ў другой палове XIX стагоддзя. Да таго ж звяртаюць на сябе ўвагу некалькі метрычных, моўна-стылёвых і іншых асаблівасцяў:

1.У тэксце з анталогіі Налэнч-Дабравольскіх назіраецца вялікая колькасць (блізу пяцідзесяці) парушэнняў метрычнае сістэмы твора: замест звыклага васьміскладовіка з'яўляюцца дзевяці-, а таксама сямі-, шасці-, дзесяці- і нават адзінаццаціскладовікі. Прычым, у пераважнай большасці выпадкаў і ў “пазнанскім" выданні, і ў “Dzienniku Literackim” парушэнняў такіх няма. Перапісвальнік Налэнч-Дабравольскіх часам без патрэбы дадаваў у радок лішняе слова або, наадварот, прапускаў слова ці склад у слове. Напрыклад:

\section{Уроцлаўскі рукапіс}

Polak chacieŭ daci swobodu Sztoby polaka zwajewaci Oj da panios że swojo hore Niby dla toj pryczyny Oj bo i niemiec uchytrość uszyŭsia Jak treba budzie słowo skazaci
“Пазнанскае” выданне /

"Dziennik Literacki"

Polak chacieu dać swobodu Sztob Palaka zwajowaci Oj da panios swaje hore Niby dla hetej pryczyny Oj! bo Niemiec w chytrość uszyusia Jak treba słowo skazaci

2.У тэксце Налэнч-Дабравольскіх выразна выяўляецца скіраванасць перапісвальніка перадаваць беларускія словы з дапамогаю ра-

1 Тут мы маем на ўвазе “падзел” на катрэны, хоць “уроцлаўскі" і “кракаўскі” рукапісы маюць іншую страфічную будову. 
сейскага пісьма. Напрыклад: joho, sztoby, biednyj polak, hołodziać, sołdat, kotoryj, czto, z Moskalom, każdomu і інш.

3. У тэксце Налэнч-Дабравольскіх даволі паслядоўна (аднак не заўсёды!) гук [ў] перадаецца літараю й (sudziŭ, daŭnymi, chacieŭ, staŭ, słaŭnoho, uieŭsia, ksiendzoŭ, ŭ Sibir i інш.). Характэрна, што ў 1850-1860-я гады сярод беларускае інтэлігенцыі толькі літаральна некалькі чалавек выкарыстоўвалі ў сваіх тэкстах літару й. Перш за ўсё, - Аляксандар Рыпінскі і Вінцэсь Каратынскі. Праўда, апошні гэтай літарай абазначаў і гук [в $]^{1}$. В. Дунін-Марцінкевіч ужываў звычайна графему и́ (у друкаваных выданнях з прычыны, што тыпаграфіі не мелі дастатковай колькасці и́, яна замянялася літараю $\boldsymbol{u}$ курсівам), хоць у Пінскай шляхще ўжо сустракаецца літара ў. Ялегі Пранціш Вуль гук [ў] перадаваў графемаю $\hat{\boldsymbol{u}}$. Іншыя тагачасныя літаратары, нават датычныя да беларускага асяроддзя, звычайна выкарыстоўвалі адно літару $\boldsymbol{u}$. Не адлюстраваны на пісьме гук [ў] у Pieredśmiertnym rozhowory Pustelnika Pietra, "Mużyckaj Praudzie", "Hutorcy Dwóch Susiedou”, а таксама перадсмяротным лісце Кастуся Каліноўскага.

4. Толькі ў гэтым тэксце перапісвальнік паслядоўна вытрымлівае ідэнтыфікацыю сялян-мужыкоў як не-палякаў: спачатку ў сорак першым катрэне - “Ci być uże moskalami - // Czy znoŭ żyć z polakami?", а пасля ў шасцідзесятым - "Bo jak staniem z polakami // Budziem roŭnye z Panami!”. У іншых варыянтах гэтае групы толькі ў сорак першай страфе чытаем падобнае: "Ci być ŭsio z Maskalami, // Ci być znoá z Palakami" ("пазнанскае" выданне) i "Czy być razom z Moskalami // Czy znou żyć z Palakami" ("кобрынскі" рукапіс). У апошняй страфе ўсіх варыянтаў гэтае групы адназначна гучыць: "Bo iak staniem Palakami // Budziem rounymi z Panami"2.

Узнікае пытанне: чым карыстаўся перапісвальнік тэксту НалэнчДабравольскіх? Сапсаванаю знаўцам расейскае мовы копіяй “пратографу” ці сам занатоўваў “на слых" (але не па памяці!) аўтарскі арыгінал?

Мы не ведаем, як трапіла Гутарка... да Марцэлі Міхала Налэнч-Дабравольскага, лекара, публіцыста, гісторыка мастацтва, удзельніка паўстання 1863 года. Паходзіў ён з "kresów”, з Валыні (маёнтак Самгарадок Сквірскага павета Кіеўскае губерні), вывучаў медыцыну ў Кіеўскім універсітэце, разам з братамі браў удзел у паўстанні, пасля стлумлення

1 у вядомых спісах Гутаркі... мы выявілі толькі адно выкарыстанне літары ц̆ у якасці гуку [в]: “Szataćsia - nie pazŭalali” [BJ 9288"II, k. 88]. Праўда, немагчыма адназначна сказаць, ці гэтак было ў арыгінале, з якога рабілася копія для Ю.Б. Залескага, ці памыліўся (?) перапісвальнік. Увогуле, адсутнасць падобнага (перадача гуку [w] літарай й) - самы значны аргумент, што В. Каратынскі не меў дачынення да Гутаркі.... Вядома, варта ўзяць пад увагу і тое, што на пачатку 1860-х гадоў ён мог адмовіцца ад таго правапісу, якім ён карыстаўся ў 1850-х гадах (Najjaśniéjszamu Jahó Miłóści... і Daliboh-to, Arcim...).

2 Падобнае назіраем у групе А (літаграфія і рукапіс). А вось у групе $\mathbf{E}$ ("парыжскае" выданне) і D (Хутёрь Старого дъдя) вытрымана адрозная ідэнтыфікацыя сялянмужыкоў і палякаў. 
якога ўцёк у Парыж¹. У 1870 г. ён пераехаў у Аўстра-Венгрыю, жыў у Кракаве [Гл.: Polski Słownik Biograficzny 1939-1946: 254; Geneologia polska, online]. 3 літаратурных і фальклорных тэкстаў, якія трапілі да яго, хутчэй за ўсё ён сам склаў трохтомную анталогію, якую2 вядомы мастак і доктар філасофіi - дапоўніў і ўжо ў пасляваенны час перадаў у аддзел рукапісаў Асалінэум.

На нашую думку, тэкст Налэнч-Дабравольскіх узнік незалежна ад “пазнанскага" выдання і публікацыі ў "Dzienniku Literackim”, паводле блізкай, але больш поўнага варыянта [можна, аднак, дапусціць, што “пазнанскія" друкары прапусцілі па няўважлівасці адну страфу (“Тат łob holać i musztrujuć...”), а рэдактары львоўскае газеты мелі свае прычыны не друкаваць шэсць строфаў пра дабрачынствы паноў для народу (“Da uże pany dla narodu // Zdaŭna chaciać dać swobodu...")]. I зусім верагодна, што менавіта яна з'яўляецца найбольш блізкай да тае копіі пратографа, якая трапіла за межы Расейскае імперыі ды стала падставай “пазнанскага" выдання і публікацыі ў газеце “Dziennik Literacki”. I нават адзначаныя намі раней “парушэнні” метрычнае сістэмы не могуць аспрэчыць дадзеную гіпотэзу: а чаму, уласна, твор, прызначаны для сялян, павінен быць напісаны класічным памерам? Не пярэчыць гіпотэзе пра адзначаны характар рукапісу, які ўключаны ў анталогію Налэнч-Дабравольскіх, і выразнае адлюстраванне ў ім уплыву расейскае мовы: у час, калі адсутнічала ўнармаваная перадача беларускае гаворкі, за ўзор магла брацца расейская пісьмовая мова з яе адметным натаваннем маўлення, прынамсі, пецярбургскага.

У той жа час на карысць нашае гіпотэзы можа сведчыць адмысловая строфіка твора. Бо толькі тут мы сустракаем не звыклы падзел тэксту на катрэны (так ёсць амаль ва ўсіх 3 захаваных варыянтах), а на часткі (строфы), якія маюць завершаны сэнс. Графічна, з дапамогаю пустога радка, афармляюцца ўсе дзевяць частак твора.

На страфічную будову Гутаркі... варта звярнуць асаблівую ўвагу: на нашую думку, адметнае кампанаванне вершаваных радкоў можа пацвердзіць гіпотэзу пра рукапіс з анталогіі Налэнч-Дабравольскіх як пра вельмі блізкі да аўтарскага. Мяркуем, што гэта ці то арыгінал, ці то копія твора, высланага (ці вывезенага) дзеля друку за мяжу. Моўныя асаблівасці тэксту дазваляюць гіпатэтычна сцвердзіць, што Гутарка... нарадзілася ў пецярбургска-маскоўскім рэвалюцыйным асяродку, на чале якога стаялі браты Каліноўскія ды Ігнацы Здановіч (1841-1863), а сябрамі былі Эдмунд Вярыга (каля 1840 - 1902), Юзаф Ямант

${ }^{1}$ Магчыма, удалося яму спачатку выехаць у Кракаў. На здымку кракаўскае фатаграфічнае ўстановы Валерыя Жавускага [Adam Chmielowski i Marceli Nałęcz Dobrowolski, online] мы бачым яго разам Адамам Хмялёўскім (1845-1916), удзельнікам паўстання 1863 года, мастаком, заснавальнікам манаскага ордэну альбертынаў і альбертынак, святога брата Альберта.

2 А таксама ўспаміны бацькавыя і ўласныя.

${ }^{3}$ Адзінае выключэнне - рукапіс, дасланы Ю.Б. Залескаму [ВЈ 9288"ш]. 
(1841 - ?), Вітальд Гажыч (каля 1843 - 1864) і інш. Калі больш дакладна - у Таварыстве польскіх студэнтаў Ogół, аснову якога складалі выхадцы з “забранага краю”, што належалі пераважна да “чырвоных". Што цікава: яны падкрэслівалі сваё "chłopomaństwo" - насілі парваныя сурдуты і боты, а замест гальштукаў - ручнікі [Nowiński, online]. Гэта было якраз тое асяроддзе, у якім магла у̌знікнуць Гутарка.... Ogół быў таварыствам з даволі значным бюджэтам, а г. зн. сродкі маглі выдавацца не толькі дзеля дапамогі бяднейшым ды набыцця кніг, але таксама і на друкаванне ${ }^{1}$ адпаведнае літаратуры ${ }^{2}$. Істотна і тое, што Ogół меў наладжаныя сувязі $з$ эміграцыяй구 а таксама 3 рознымі патрыятычнымі і навуковымі арганізацыямі4 былое Рэчы Паспалітае. I не менш важна: студэнты, выязджаючы на святы і вакацыі ў родныя мясціны, вялі прапаганду сярод сялян. Ці ж не прызначалася дзеля гэтае працы студэнтаў Гутарка...?

“Пазнанскае” выданне, як ужо адзначалася, захавалася ў адным асобніку. Застаецца невядомым, чаму гэты асобнік быў далучаны да справы № 322, якая называлася O девице Марцынкевич в Минске, которая чрезмерно выказывала польский патриотизм. Якім чынам ён трапіў у рукі жандараў? Быў канфіскаваны ў Мінску падчас затрыманняў і арыштаў?

Даследнікі, як вынікае з іхніх дапушчэнняў, лічылі, што выданне было ажыццёўлена ці то недзе за мяжою, ці то Б. Шварцэ ў Беластоку. Аднак, як даводзіць, Т. Настульчык, друк высокае якасці ў ручной беластоцкай друкарні выканаць было немагчыма. Значыць, пад увагу можна браць толькі прафесійную друкарню. Але дзе і якую?

Перш за ўсё трэба сказаць, што выдавецкі адрас, пададзены ў кніжачцы, сапраўды існаваў. У Пазнані ў тыя часы дзейнічала друкарня Напалеона Каменьскага і суполкі5, пры якой мелася таксама адмысло-

${ }^{1}$ Надрукаваць невялікую кніжачку за мяжою не патрабавала вялікіх сродкаў. Напрыклад, М. Акілевіч меркаваў за 55 рублёў срэбрам выдаць 10 тысяч асобнікаў кніжкі, у склад якое ўваходзіла празаічная Gromata Wylniaus Senelio і вершаваная Pasaka Senelio. [Гл.: Революционный подъем... 1964: 26].

${ }^{2}$ Цікава адзначыць: як паведамляе Францішак Навінскі, студэнт Юзаф Бярнацкі (пэўна, той самы, які пазней будзе завербаваны III аддзяленнем!) прывёз з-за мяжы ў Пецярбург блізу тысячы асобнікаў “odezw”. [Гл.: Nowiński, online]. У нас няма падстаў ідэнтыфікаваць дадзеныя "odezwy” як Гутарку.., але той факт, што яны друкаваліся не ў Пецярбурзе ці Расіi, паказальны - Ogół мог выдаць беларускамоўны твор за мяжою.

3 Высылалі ахвотнікаў у польскія вайсковыя школы Л. Мераслаўскага, што дзейнічалі спачатку ў Парыжы, а пасля ў і Генуі.

${ }^{4}$ Вядома, што Віктар Каліноўскі падтрымліваў дачыненні з бібліятэкай Асалінскіх у Львове, Адамам Кіркорам у Вільні ды інш.

5 Напалеон Каменьскі (1806-1873) паходзіў з Пазнані, вывучаў права ў Берлінскім універсітэце. Браў удзел у паўстанні 1830-1831 гг., у тым ліку і на Літве. З 1839 года займаўся выдавецкаю справаю і кнігагандлем. У 1841 годзе разам з вядомым філосафам Каралем Лібельтам (1807-1875) ды гісторыкам і публі- 
вая кнігарня. У надрукаваным каталогу [Katalog dzieł... 1858] друкарні і кнігарні пералічана блізу 1500 пераважна польскамоўных выданняў 1830-1850-х гадоў, у тым ліку найважнешыя віленскія выданні ${ }^{1}$.

Што датычыць "спонсара" беларускага выдання А. Курнатоўскага, то Бібліяграфія Эстрахера ведае толькі W. Kurnatowskiego, які падрыхтаваў і выдаў у 1843 годзе Mapę W. Księstwa poznańskiego [Bibliografia polska... 1881: 436; Łukaszewicz 1860: 635]. Відавочна, тут маецца на ўвазе Віктар Курнатоўскі (1810-1846), вядомы пазнанскі картограф, літограф і дзеяч Towarzystwa Demokratycznego Polskiego. Па няпэўных звестках паходзіў ён з Літвы, а на Пазнаншчыне апынуўся пасля паўстання 1830-1831 гадоў. I нібыта менавіта тут ён стаў карыстацца прозвішчам Курнатоўскі. Ці меў да Віктара Курнатоўскага якое дачыненне A. Kurnatowski, - высветліць не ўдалося². Мажліва, аднак, што А. Курнатоўскі - гэта Уладзімір Аляксандар Курнатоўскі (1818-1884), паўстанец 1863 года [Гл.: Włodzimierz Aleksander Kurnatowski..., online; Polski Słownik Biograficzny 1971: 246]. (Ягоны маёнтак Курнатовічы знаходзіўся ў некалькіх дзясятках кіламетраў ад Імберова пад Аборнікамі).

Таксама не змаглі мы даведацца, хто на пачатку 1860-х гадоў валодаў Imbierowem pod Obornikami; але цікава тое, што фальварак Імберова Аборніцкага павету [Гл.: Słownik geograficzny... 1882: 275] яшчэ ў 1850-я гады быў часткаю маёнтка Зелянткова [Гл.: Słownik geograficzny... 1895: 590] Энджея Марачэўскага, які колісь быў супольнікам Н. Каменьскага.

Усё гэта не дазваляе адназначна сцвердзіць, што выдавецкі адрас Гутаркі... цалкам быў выдуманы тымі, хто займаўся друкаваннем твоpa $^{3}$. Праўда, аніякіх іншых кніг, "прафінансаваных" А. Курнатоўскім і выдадзеных суполкаю Н. Каменьскага, выявіць нам не ўдалося. Звычайна Н. Каменьскі выдаваў свае кнігі ўласным "nakładem". Варта працягваць пошукі ў гэтым кірунку.

Невядомыя нам і акалічнасці публікацыі Гутаркі... ў “Dzienniku Literackim”". Бо хоць у газеце і маецца прадмова да беларускамоўнага тэк-

цыстам Энджеем Марачэўскім (1802-1855) заснаваў кнігавыдавецкую суполку. Рэдагаваў “Gazetę Wielkiego Księstwa Poznańskiego” (1846-1865) і інш.

${ }^{1}$ Напрыклад, Piosenki wieśniacze Яна Чачота 1837, 1840, 1844 гадоў.

2 Міцкевічазнаўцам вядомы таксама нехта М. Курнатоўскі, які, відаць, у Кракаве выканаў медаль з бюстам Адама Міцкевіча і на адвароце адкрытую кнігу з надпісам "Pan Tadeusz. Dziady. Sonety. Wallenrod”. [Гл.: Méyet 1888: 39].

3 Мы шукалі “кропак судакранання” Гутаркі... 3 пецярбургскаю друкарняю Ёзафата Агрызкі (1827-1890). Падобнасць шрыфтоў, аднак, гэта адзіны аргумент на карысць гіпотэзы. (Можа, яшчэ - “народавольніцкія” погляды самога выдаўца). Куды больш “тэхнічнага" (якасць друку, афармленне нумарацы старонак, колькасць радкоў на старонцы) падабенства Hutorki... знаходзім з выданнямі Н. Каменьскага і суполкі.

4 Газета была заснаваная Войцехам Манецкім (1820-1887) як штотыднёвік (выходзіла ў аўторкі і пятніцы) у 1852 годзе і выдавалася да 1870 года. (У 1855 годзе як “Nowiny”). Рэдактарам у 1854-1865 гадах быў публіцыст і пісьменнік Ян Дабжаньскі (1820-1886). 
сту, але яна датычыць, уласна, не яго, а праблемы “падзелу” славянскіх моў і дыялектаў. Відавочна, філолаг (вывучаў філалогію ў Львоўскім універсітэце, хоць дыплома і не атрымаў) Ян Дабжаньскі, не падзяляючы погляды "русінаў"1, выкарыстаў нагоду дзеля палемічных мэтаў:

Даслалі нам сялянскі твор (poezję ludową) на беларускім дыялекце. Змяшчаем яго тут як дзеля ягонага зместу, так і дзеля мовы. Нашыя русіны (Rusini), апелюючы заўсёды да сваіх дванаццаці мільёнаў, улічваюць і тых, хто размаўляе і на беларускім дыялекце. У той час як гэты люд, самы шматлікі з усіх рускіх плямёнаў (szczepów ruskich), размаўляе на мове, якая да польскае значна больш блізкая, чым да якога іншага дыялекту. Хутчэй гэтую мову зразумее паляк, русін жа - толькі той, хто добра ведае польскую, дык з дапамогаю польскае мовы. Увогуле трэба сказаць, што ўсе Pyсі (Rusie wszystkie) ажно да XVI стагоддзя карысталіся адною пісьмоваю моваю, аднак не сваёю ўласнаю, а перанятаю $з$ царкоўных кнігаў, старабалгарскаю, таксама як на захадзе Еўропы лацінская мова 3 касцельных кнігаў была пісьмоваю моваю ўсяе Еўропы. Калі ж народы пачалі адмаўляцца ад лаціны і прымалі нацыянальныя мовы ды пераўтваралі іх на пісьмовыя, Русь разам з палякамі (Ruś wraz z Polakami) выпрацавала са свае і мазурскага дыялекту пісьмовую польскую мову. Аднак мясцовыя рускія дыялекты засталіся аж да сёння некранутымі і не зблізіліся адзін да аднаго. Прыхільнікі люду, што сёння арганізоўваюць сялянскія школкі на Палессі, аб'явілі конкурс на лемантар на палескім дыялекце, на Валыні - на валынскім, а на Украіне - на ўкраінскім. Нашыя ж рускія школьныя кніжкі не будуць зразумелыя ані на Украіне, ані на Беларусі [Hutorka staroho dzieda 1861, 89: 714].

Відаць, для Я. Дабжаньскага прапольская скіраванасць беларускага твора была істотным аргументам у польска-русінскіх дыскусіях тых часой: беларусы, “самы[я] шматлікі[я] з усіх рускіх плямёнаў”, далучаюцца да “польскае справы”, а вось шмат якія русіны - скіроўваюць свае погляды ў бок маскалёў.

У Львоў Гутарка... магла трапіць рознымі шляхамі, але не было гэта “пазнанскае” выданне2 . Дасланы, відаць, быў рукапіс, вельмі блізкі да тэксту Налэнч-Дабравольскіх. Яшчэ раз паўторым: неадлюстраванне акання (больш дакладна: непаслядоўнае адлюстраванне) на пісьме можа сведчыць пра ўплыў расейскае пісьмовае мовы, а г. зн. куды больш імаверна, што дадзены варыянт беларускамоўнага твора ўзнік у колах ліцвінскае і польскай моладзі Ogółu, а не ў інтэлігенцкіх асяродках Вільні, Мінска ці Віцебска, бо і В. Дунін-Марцінкевіч, і У. Сыракомля, і А. Вярыга-Дарэўскі адлюстроўвалі аканне на пісьме.

Блізкім, хоць і неідэнтычным да папярэдніх быў і рукапіс, на аснове якога ўзнік варыянт-копія, дасланая Ю.Б. Залескаму. На нашую думку, гэты рукапіс варта датаваць 1860-мі гг., а не 1880-мі. Сведчаннем можа

1 У сярэдзіне XIX стагоддзя значная частка насельніцтва Галіцыі называла сябе русінамі, ці рускімі, але дзялілася на г. зв. старарусінаў (маскаляфілаў) і младарусінаў (украінафілаў).

2 Пра гэта можа сведчыць дадатковая страфа (“Тam łob holoć i musztruiuć...”), а таксама адсутнасць шасці строф пра добрых паноў (“Da ŭże pany dla narodu...”). 
быць даўняе напісанне асобных літараў (напрыклад, $\boldsymbol{s}$ ). 3 найбольш значных адметнасцяў копіі Ю.Б. Залескага адзначым тое, што перапісвальнік захаваў напісанне літары й (хоць і незаўсёды, часам гук [ў] перадаецца літараю $\boldsymbol{w}$. Напрыклад, chodzić w ryzach, dawniej, pryniaw, krywdziać і інш.), а таксама неадлюстраванне акання. Характэрна і тое, што ён пакінуў свой, відавочна, украінскі ці палескі след: напрыклад, szczob, świt, szczo і інш. Радок "Na prykaz siejczas jaŭlaćsia" перапісвальнік прапусціў, а вось да радка "Sam ŭ czużoj ziemli nieboże!" дадаў сваю ${ }^{1}$ версію: "Na ziemli swoioj - czużoj nieboże".

На залежнасць гэтага варыянта ад пратографу (?) можа паказваць і ейная строфіка: тут паўтораны падзел радкоў на фрагменты як і ў рукапісе Налэнч-Дабравольскіх з той толькі розніцаю, што замест "пустых" радкоў з'яўляюцца альбо знак \# (hash) ці = (equals sign), альбо меншы водступ першага радка фрагменту.

Перапісвальнік карыстаўся невядомым рукапісам, але не ўзнаўляў тэкст па памяці.

Выяўлены Т. Настульчыкам расейскамоўны Хутёрь Стараго дъдя - гэта, на нашую думку, пераклад асобнай рэдакцыі твора, што мы адносім да групы D. Гэтая рэдакцыя ўзнікла на падставе першаснага тэксту Гутаркі..., але ўтрымлівала таксама фрагменты, якія маюцца і ў “парыжскім" выданні. Праўда, аўтар (ці сааўтар) яшчэ моцна трымаецца першаснай ідэі твора - дапамагчы сялянам правільна адказаць на пытанне "рэферэндума". Як і ў варыянтах папярэдніх групаў (A, B і C), тут не заўважаецца, аўтар ведае пра сялянскую рэформу 19 лютага 1861 года. Ён згадвае адно толькі чуткі пра "волю", якім просіць не верыць. Г. зн. тэкст, з якога быў зроблены пераклад, узнік не пазней сакавіка 1861 г.

Памятаючы пра гіпотэзу 3. Тальвірскае, што і беларускі, і літоўскі тэксты Гутаркі... з'яўляюцца перакладамі з невядомага польскага арыгінала, увесь час непакоіла думка: а можа, расейскамоўная гутарка і ёсць тым арыгіналам? Маўляў, нехта з Ogółu, добра ведаючы расейскую мову і расейскае вершаскладанне выклаў у даступнай для сялян форме ідэю далучыць люд беларускіх губерняу да нацыянальна-вызваленчае барацьбы за адраджэнне Рэчы Паспалітае - Польшчы. Гэты нехта, відавочна, ведаў, што беларускі селянін, адносна кепска разумеючы і з асцярогаю ставячыся да польскае мовы, за часы расейскага панавання прызвычаіўся выконваць расейскамоўныя распараджэнні царскае ўлады. Расейскамоўнае ўспрымалася сялянствам як загад, абавязковы да выканання, а г.зн. мела шанец быць ім прынятым. Прынамсі, напісанае па-польску такіх шанцаў у сярэдзіне XIX стагоддзя, хіба, ужо не мела.

1 Зрэшты, дадатковы радок напісаны -хутчэй за ўсё - пазней i, здаецца, іншаю рукою. Апрача таго, тут замест графемы $\dot{\boldsymbol{z}}$ ужытая $\check{\boldsymbol{z}}$ (двойчы). 
Зрэшты, нават сама наяўнасць захаванага перакладу даводзіць: на пачатку 1860-х гадоў існавала думка пашыраць агітацыю пры дапамозе расейскамоўных тэкстаў сярод насельніцтва беларускага і літоўскага краю. Сапраўды, не на расейскіх жа сялян ці расейскіх жаўнераў планавалі ўздзейнічаць польска-ліцвінскія рэвалюцыянеры. Мы не сумняваемся, што пераклад рыхтаваўся з менавіта такімі мэтамі. Гэта не быў пераклад на патрэбы царскай адміністрацыі: дзеля следства дастаткова было б і падрадковага тлумачэння Гутаркі....

Цікава адзначыць, што пераклад быў занатаваны на паперы Пецярбургскае фабрыкі Джона Гобарда⒈ Вядома, той факт, што перакладнік карыстаецца папераю пецярбургскае фабрыкі, адназначна не азначае: тэкст быў напісаны ў Пецярбурзе, але верагоднасць гэтага вельмі вялікая ${ }^{2}$.

Рукапіс дэманструе даволі невысокія паэтычныя здольнасці перакладніка. I нават "рэдактарскія" праўкі - іх даволі шмат - не змаглі прывесці тэкст да правільнае расейскае мовы.

Звернем увагу на некаторыя асаблівасці перакладу. Найважнейшае тое, што перакладнік моцна трымаецца беларускага арыгіналу, перакладае літаральна, слова ў слова, часам захоўваючы беларускія словы:

“Пазнанскае” выданне

Szto uże na świecie budzie?

Ale nie moh ratawaci

Mużyk mieŭ odkul wziać chleba

Jeszczo sam idzi u sałdaty

Chadzić u ryzach z baradami

Z duszy rekrut i padatki

Ależ bratki nie tużycie

Choć prastaki wymyszlajuć
Хутёрь Стараго дпдя

Что уже на свњть буди?

Но не могъ Спасти

Мужикъ имълъ откуда взять хльба

Еще самъ иди въ|солдаты

Ходить въ|рясахъ, съ бородами

Изъ души рекрутъ, податки

Но братки не тужите

Хотя Умники вымишляютъ

Часам ён не знаходзіць адэкватных сродкаў ці не разумее арыгінала:

“Пазнанскае” выданне

Jak Maskál taho daczuusia,

To na jeho nawiernuŭsia

Szle usich damoj, choć nie znaje,

Ci katory dom swoj maje!

Stau kaścioły odbiraci

\section{Хутёрь Стараго дпдя}

Какъ москалъ осмотрьлся

Такъ на него обратился

Иди домой, хотя не знаетъ

Кто свой домъ имъетъ.

Сталъ Костёлы обирать

1 Пра гэта сведчыць цісненне ў левым верхнім куце першае старонкі: “<...> ФАБР. 1835 ГОБАРДА”. Маецца на ўвазе папяровая фабрыка Джона Гобарда і Аляксандра Варгуніна ў Пецярбурзе: “въ 6 верстахъ отъ С. Петербурга - большая бумажная фабрика Гобарта и Варгунина”. [Гл.: Павловскій 1843: 29]. Сёння гэтае прадпрыемства ў літаратуры звычайна называецца Акционерное общество Невской писчебумажной фабрики в С.-Петербурге, а яе заснавальнікамі лічацца купец 1-е гільдыі А. Варгунін і падданы Велікабрытаніі Джон Гоберт (!). [Гл.: Невская писчебумажная фабрика, online].

2 У Беларусі і Літве ў сярэдзіне XIX стагоддзя дзейнічала значная колькасць уласных папяровых фабрык (млыноў). Напрыклад, Ян Чачот выкарыстоўваў паперу фабрыкі Кіаўтан (Kiauten), сёння в. Смірнова Калінінградскае вобласці. 
I akcyzju ustanawili To Maskal i znoŭ ŭziaŭ wolu A sztob bolsz nie wajawaci, Da i narodu nie cieraci Czuć i nas majuć pytać sia I każen zapłacić nieboże Szak pany nieprarabili, Jak ich ŭ Sybir wałaczyli, Jak ŭsiu szlachtu kasawali, I majontki odbirali
Какъ Окцызу погубили

Тагда москаль размогся въ воле

И чтобъ больше не воевать

Чтобъ людей не принуждать

Слышно и у насъ будетъ требоватся

Скажуть заплати бъдный

Въдь Паны ничего не успьли

Какъ въ Сибиръ ихъ толкали

Какъ всю шляхту уничтожили

И Имьнія отобрали нальныя:

Праўда, сяды-тады ягоныя мастацкія рашэнні дастаткова арыгі-

“Пазнанскае” выданне

Dauniéj ludzie dobra żyli I druhich dobra uczyli Wałacze od siemii z chaty Bo uże pora nastupaje, Szto Maskal moc pacieraje Oj baj Niemiec ŭ chitrość uszyŭsia A Prancuzy jak daznali Zaraz na nieho napali A jak tolki szto nakaże, Każm zrabić, jak prykaże Oj tak! tak to moi ludzie, Z Maskalem dobra nie budzie

Usim szczaście Boh nam daść, I prapadzie Maskouska właść!!!.

\section{Хутёрь Стараго дпдя}

Да́вно люди Бога знали Другихъ добру научали Какъ собаку тащитъ съ хаты Ибо уже время наступила Московская лопнет сила Ой! ибо и нъмецъ у Лисовъ научился Какъ Французы того Узнали Бъду На Нђмцев навязали И лишь только что прикажеть То пляшеть каждый какъ панъ скажетъ Помолитесь добрыя люди Съ Москалемъ добра не|будетъ То пусть же этотъ бъсъ Идет отъ насъ въ сухій льсъ 1 Всьмъ Намъ Богъ счастье дасть Когда отвяжется от Насъ напасть

Што выкарыстаў у якасці арыгіналу перакладнік? Гэта не быў аніводзін з вядомых сёння тэкстаў. Іншы, у якім, прытрымліваючыся ідэйнае канвы варыянтаў групы А, В і C (выказацца на "рэферэндуме" на карысць далучэння да Польшчы), аўтар беларускамоўнага арыгінала падае шэраг новых аргументаў, якіх не было ў творы раней (маскаль мае “волю” адным словам ператварыць ксяндза ў "шызматыка"; пана, за тое, што ён хоча вызваліць сялян, - "у когти забралъ"; пра "вольносць” маскаль загаварыў пасля таго, як яму “задалі у Крыме духу” і патрабаванні французаў выдае цяпер за свае жаданні).

Застаецца дадаць, што невядомы сёння варыянт Гутаркі... быў пакладзены і ў аснову “парыжскага" выдання. Адрэдагаванага так, што амаль не засталося “слядоў” “рэферэндума”. Таго, уласна, дзеля чаго і пісаўся твор.

Гэтае “парыжскае" выданне Hutorki staroho dzieda мы аднеслі да групы Е. На нашую думку, гэта новая рэдакцыя твора. З’явілася яна

1 Відаць, апошнія два радкі былі ў тэксце, з якога зроблены пераклад. 
ў другой палове 1861 года ${ }^{1}$. (Лічым, што дата на апошняй старонцы зборнічка - "1862 r. Lutego 27 [15] dnia" - адпавядае сапраўднасці). Цікава тое, што ў архівах захаваліся ажно некалькі асобнікаў выдання (тры цалкам і фрагменты чацвёртага), але рукапісныя копіі пакуль не выяўленыя².

Даследнікам удалося часткова разгадаць таямніцу друку Hutorki...: сёння, здаецца, няма сумненняў, што яна ўбачыла свет у беластоцкай “друкарні" Б. Шварцэ. Ён сам пра гэта пісаў наступнае:

Прыхільнікамі чырвонага, паўстанцкага руху была галоўным чынам моладзь з забранага краю; першым, менавіта заснавальнікам паўстанцкага камітэта, які меўся стаць пазней Цэнтральным, быў паэт Апалон Кажанёўскі з Украіны, швагер Стэфана Баброўскага; да яго далучыліся Ігнацы Матушэвіч, таксама украінец, і калішанін Баляслаў Дэнель, самы актыўны з усіх. Праца не ладзілася з прычыны апазіцыі белых, толькі ўрадавы пераслед павярнуў усіх на шлях змовы. Па даручэнні гэтага першапачатковага камітэта і прывезеным Дэнелем у Беласток шрыфтам я друкаваў на плябаніі з Грынявіцкім па-беларуску лацінскімі літарамі рэвалюцыйную народную Hutorkę staraho dzieda, якая павінна была пераканаць літоўскі люд, што толькі ад польскае Рэчы Паспалітае ён атрымае “зямлю і волю” [Szwarce 1903: 444].

На жаль, мы не маем дастаткова матэрыялаў, каб высветліць, калі дакладна была выдадзена Гутарка.... Паспрабуем, аднак, прасачыць тыя падзеі, ад якіх залежала друкаванне твора.

Па-nершае, "паўстанцкі камітэт" - гэта Komitet Miejski, ці Komitet Ruchu, быy̆ створаны паэтам Апалонам Кажанёўскім (1820-1869) пасля ўвядзення расейскаю ўладаю 14 кастрычніка 1861 г. ваеннага стану; у яго склад уваходзілі: Леон Главацкі (брат Баляслава Пруса), Ігнацы Хмяленьскі (1837-1871) і Вітольд Марчэўскі (1832-1903). Праўда, кіраўніка Камітэта жандары арыштавалі 21 кастрычніка 1861 г. Што цікава: перад арыштам А. Кажанёўскі пісаў у Віцебск А. Вярыгу-Дарэўскаму:

Пісьмо Ваша, без даты, але мілае сэрцу, што любіць нават самыя забытыя куткі сваёй зямлі, атрымаў чатыры дні назад <..>. Затрымка выйшла з прычыны немагчымасці адпісаць у гэтыя страшныя дні стану аблогі, хаця гэты стан пераносіцца мужна і стойка... Наконт карэспандэнцыі і хуткай - прашу. Павінна яна быць маладой паводле думкі і напісаная жывым словам... Памятайце, што 3/15 лістапада першы нумар выйдзе. Прысылайце, што маеце нават найменшага на беларускай мове: я павінен паглядзець, што гэта такое. Так, не прачытаўшы, рашыць не магу...

${ }^{1}$ Нягледзячы на тое, што ў грамадстве шырока абмяркоўвалася сялянская рэформа 19 лютага 1861 года, у “парыжскім" выданні гэты аспект (“воля”, дадзеная царом) не адлюстраваны. Магчыма, з тае прычыны, што выдаўцы нічога свайго не дадавалі, а толькі выкасоўвалі “састарэлы рэферэндум" з тэксту, які быў напісаны ўласна да апублікавання царскага маніфесту.

2 Не бяром пад увагу копіі з хрэстаматыі Б. Эпімаха-Шыпілы і ў матэрыялах А. Ельскага: абедзве ўзніклі пазней як вынік збіральніцкай дзейнасці. 
Асабліва хацеў бы мець драмку, думка якой невымоўна мне падабаецца [Цыт. па: Кісялёў 1971: 193].

Г. Кісялёў, які апублікаваў гэты ліст А. Кажанёўскага, лічыў, што напісаны ён у верасні-кастрычніку 1861 г. і датычыць публікацыі твораў А. Вярыгі-Дарэўскага ў планаванай газеце "Dwutygodnik". Але звернем увагу на тое, што адпраўнік піша пра "страшныя дні стану аблогі", г. зн., пра ваенны стан у Варшаве, а таксама на эзопавую мову ліста (“Павінна яна быць маладой паводле думкі і напісана жывым словам”). Ці не ішла тут гаворка не толькі пра “звычайныя" літаратурныя творы, але і тыя, якіх патрабаваў час, патрабавала справа, якою займаўся А. Кажанёўскі? Думаецца, А. Вярыга-Дарэўскі (паводле некаторых звестак адзін з кіраўнікоў вызваленчага руху на Віцебшчыне) добра разумеў, якую літаратуру - легальную і нелегальную - трэба выдаваць у сітуацыі, якая склалася. I цікава было б даведацца: што́ выслала Беларуская Дуда ў кастрычніку-лістападзе 1861 года ў Варшаву? Бо няварта сумнявацца, што ў Беласток Гутарка... трапіла праз Варшаву. I магчыма нават, даслаў яе А. Вярыга-Дарэўскі. Прынамсі, мы не ведаем пра кантакты каго-небудзь яшчэ з беларусаў з Komitetem Miejskim.

Па-другое, найважнейшую ролю ў справе друку Гутаркі... адыграў Б. Шварцэ (1834-1904), які ні паходжаннем, ні нараджэннем (прыйшоў на свет у Францыі ў сям'і польскіх эмігрантаў) не быў звязаны з ЛітвоюБеларуссю, а таму рэдагаваць беларускамоўныя тэксты ён наўрад ці мог ${ }^{1}$. Б. Шварцэ адно выконваў заданне Komitetu Miejskiego ${ }^{2}$, якому падпарадкоўваўся, працуючы з 1860 года па май 1862 года на Беласточчыне на будаўніцтве Пецярбургска-Варшаўскае чыгункі.

Па-трэцяе, выканаць заданне Komitetu Miejskiego стала магчымым тады, калі Б. Дэнель прывёз у Беласток “шрыфты”, г. зн. невялікі ручны друкавальны станок. Калі гэта адбылося? Вядома, што Б. Дэнель (1830-1863), пасля арышту ў лістападзе 1860 г. і вызвалення з Варшаўскай цытадэлі 30 сакавіка 1861 года, пэўны час удзельнічаў у рэдагаванні газеты-ўлёткі “Strażnica”. Яна выходзіла ў Варшаве 31 ліпеня 1861 года. У гэтым жа годзе, зусім верагодна - пасля 14 кастрычніка, яго зноў арыштавалі і выслалі на Беласточчыну, дзе ён працаваў на будаўніцтве Пецярбургска-Варшаўскае чыгункі. Відаць, толькі позняй восенню 1861 г. Б. Шварцэ атрымаў “шрыфты” і адначасна даручэнне Komitetu Miejskiego, што ён павінен друкаваць (i распаўсюджваць?) свае выданні для беларускамоўных сялян Беласточчыны, Віленшчыны і Гародзеншчыны.

1 Мажліва, аднак, што Б. Шварцэ някепска разумеў беларускую мову. Пра гэта могуць сведчыць ягоныя ўспаміны Siedem lat w Szlyselburgu, напісаныя ў 1893 годзе: "Szeroko się uśmiechnął jasnowłosy jamszczyk, zdjął niski czarny kapelusz, i słodziutko przemówił: barin, na wodku, za to, czto szczasliwo prywioz! Musiałem się roześmiać, tak mi się podobała ta niewinna ironia Moskala - nie pamiętam, com mu z białoruska odpowiedział: sztob ty prapau, albo coś podobnego" [Sywarce 1893: 4].

2 Нягледзячы на тое, што А. Кажанёўскі знаходзіўся ў Варшаўскай цытадэлі, справа друку агітацыйнае беларускамоўнае літаратуры пачаў, відаць, ён. 
Новая рэдакцыя Гутаркі... адлюстроўвала пазіцыю варшаўскіх чырвоных, а менавіта, курс на ўзброенае паўстанне, якое меркавалася пачаць 26 чэрвеня 1862 г. 3 гэтае прычыны ў вядомым у той час тэксце скасавалі строфы з заклікамі “правільна" галасаваць на "рэферэндуме", а дадалі ${ }^{1}$ больш актуальныя:

$$
\begin{aligned}
& \text { Na wiasnu jak daść Boh hranieć } \\
& \text { Prancuz - Palak z żaunierami, } \\
& \text { J jak Polszcza usia ustanieć } \\
& \text { Idziom i My z Palakami. } \\
& \text { <..> } \\
& \text { Usim szczaście Boh nam daść, } \\
& \text { I prapadzie Maskouska właść!!!. }
\end{aligned}
$$

Дзе, калі і кім было гэта зроблена? Відавочна, не ў Варшаве. Мы лічым, што “ланцужок” ад А. Вярыгі-Дарэўскага (а можа, і “віцебскае паэтычнае школы”) да А. Кажанёўскага і Komitetu Miejskiego мог доўжыцца да Б. Шварцэ і "парыжскага" выдання Гутаркі.... А ўключэнне ў зборнічак верша Dobryja wieści можа быць адно на карысць гіпотэзы пра непасрэднае дачыненне вядомых літаратараў Літвы-Беларусі да "парыжскага" выдання: верш У. Сыракомлі не быў шырокавядомым, але яго маглі мець блізкія прыяцелі літоўскага лірніка.

\section{Бібліяграфія}

Abramavičûs Vladas. 1949. Bibliografiâ po belorusskoj literature. Hudožestvennye i publicističeskie proizvedeniâ, opublikovannye i rukopisnye [mašynapìs]. Vil'nûs [Абрамавичюс Владас. 1949. Библиография по белорусской литературе. Художественные и публицистические произведения, опубликованные и рукописные (машынапіс). Вильнюс].

Adam Chmielowski i Marceli Nałęcz Dobrowolski [online] https://www.ipsb.nina.gov.pl/a /foto/adam-chmielow ski-i-marceli-nalecz-dobrowolski [dostup : 24.06.2019].

[Akelaitis Mikalojus]. 1906. Litovskiâ pis'ma, kotoryâ predpoloženo bylo napečatat' v Memelě. Pis'mo starika iz Vil'ny. Pis'mo bědnâka iz Litvy. V: Sbornik dokumentov muzeâ Grafa M.N. Murav'eva. T. 1. Vil'na [Akelaitis Mikalojus. 1906. Литовскія письма, которыя предположено было напечатать въ Мемелп. Письмо старика изь Вильны. Письмо бпдняка изь Литвы. В: Сборникъ документовъ музея Графа М.Н. Муравьева. Т. 1. Вильна].

Archiwum Główne Akt Dawnych (AGAD), zespół 378: Archiwum Prozarów i Jelskich, 1401: Materyały bibliograficzne z zakresu literatury białoruskiej uzbierane przez Al. Jelskiego.

Awejde Oskar. 1965. Rola prasy rewolucyjnej w powstaniach 1831 i 1863 roku [styczeń 1866]. W: Zbiór zeznań śledczych o przebiegu powstania styczniowego. WrocławWarszawa-Kraków.

Barysenka Vasìl'. 1957. Francìšak Bagušèvìc ì prablema rèalìzma ǔ belaruskaj lìtaratury XIX stagoddzâ. Mìnsk [Барысенка Васіль. 1957. Францішак Багушэвіч і праблема рэалізма ў беларускай літаратуры ХІХ стагоддзя. Мінск].

Belaruskì dzâržaǔny arhìǔ lìtaratury ì mastactva (BDALÌM), f. 66: Bèndè Lukaš Apanasavič, vop. 1, spr. 993: Gutarka staroga dzeda. Verš. Pis'ma starika iz Vil'ni. Publicystyčny

${ }^{1}$ Больш дакладна: перапрацавалі страфу з літаграфіі, дзе ішла гаворка пра Л. Мераслаўскага. 
tvor. Mašynapisnyâ kopì̀ [Беларускі дзяржаўны архіў літаратуры і мастацтва (БДАЛіМ), ф. 66: Бэндэ Лукаш Апанасавіч, воп. 1, спр. 993: Гутарка старога дзеда. Верш. Письма старика из Вильни. Публіцыстычны твор. Машынапісныя копіi].

Belaruskaâ litaratura XIX stagoddzâ: Hrèstamatyâ. 1971. Sklad. S. Aleksandrovič, A. Lojka, V. Ragojša. Mìnsk [Беларуская літаратура XIX стагоддзя: Хрэстаматыя. 1971. Склад. С. Александровіч, А. Лойка, В. Рагойша. Мінск].

Bibliografia polska XIX stulecia przez K. Estreichera. 1881. T. VI: Dopełnienia (A-O). Kraków.

Biblioteka Jagiellońska (BJ), sygn. 9288III: Wiersze różne przesłane Józefowi Bohdanowi Zaleskiemu.

Central'nij deržavnij ìstoričnij arhìv Ukraïni (CDÌAK Ukraïni), f. 442: Kancelâriâ kï̈vs'kogo, podil's'kogo ì volins'kogo general-gubernatora, m. Kï̈v, op. 812, spr. 4 [Центральний державний історичний архів України (ЦДІАК України), ф. 442: Канщелярія київського, подільського і волинського генерал-губернатора, м. Київ, оп. 812, спр. 4 [online] https://cdiak.archives.gov.ua/v_do_150_pochatku_Polsko go_povstannya_1863-1864.php [доступ: 18.03.2020].

Dunìn-Marcìnkevìc Vìncènt. 2008. Zbor tvoraǔ u 2 t. T. 2: Veršavanyâ apovescì ì apavâdannì, veršy, publicystyka, lìsty ì paslannì, peraklady, Dubia. Mìnsk [Дунін-Марцінкевіч Вінцэнт. 2008. Збор твораў у 2 m. Т. 2: Вершаваныя аповесці і апавяданні, вершы, публіцыстыка, лісты і пасланні, пераклады, Dubia. Мінск].

Èlektronnye opisi [Электронные описи] [online] http://statearchive.ru/383 [доступ: 18.03.2020].

Garèckì Maksìm. 1920. Gìstoryâ belaruskae littèratury. Vìl'nâ [Гарэцкі Максім. 1920. Гicторыя беларускае літэратуры. Вільня].

Garèckì Maksìm. 1926. Gìstoryâ belaruskae litèratury, vydan'ne čac'vertae, peraroblenae. Mensk [Гарэцкі Максім. 1926. Гісторыя беларускае літэратуры, выданьне чацьвертае, пераробленае. Менск].

Geneologia polska [online] https://polishgenealogy1.blogspot.com/2017/04/dobrowol ski.html [dostup: 25.06.2019].

Genealogia Polaków: Katalog Powstańców Styczniowych [online] https://genealogia.okie m.pl/powstanies/index.php?nazwisko=Piekarski [dostup: 28.09.2019].

Generalitet rossijskoj imperatorskojarmii i flota [Генералитет российской императорской армии и флота [online] http://www.rusgene ral.ru/general_r1.html [доступ: 13.09.2019].

Gosudarstvennyj arhiv Rossijskoj Federacii (GARF), f. 109, op. 37: I èksped., 1862 g., d. 228: $O$ dvuh vozmutitel'nyh stihotvoreniâh na malorossijskom âzyke pod zaglaviem ZNAJTE LÛDE DLÂ ČEGO CAR' VIS'KO TREMAE $i$ TUČA VREMEN PROŠEDŠIH I NASTOÂŜIH, najdennyh podbrošennymi neizvestno kem v uezdah: Gajsinskom - Podol'skoj i Umanskom - Kievskoj gubernij [Государственный архив Российской Федерации (ГАРФ), ф. 109, оп. 37: І экспед., 1862 г., д. 228: О двух возмутительных стихотворениях на малороссийском языке под заглавием ЗнАйтЕ ЛюдЕ для чЕГО ЦАРЬ ВИСЬКО ТРЕМАЕ И ТУЧА ВРЕМЕН ПРОШЕДШИХ И НАСТОЯЩИХ, НайӘенНЫХ подброшенными неизвестно кем в уездах: Гайсинском - Подольской и Уманском Киевской губерний [online] http://opisi.garf.su/default.asp?base=garf\&menu= $2 \& \mathrm{v}=7 \&$ node=348\&cd=1322823\&fond=11 47\&opis=9160\&delo=5754607 [доступ: 18.03 .2020$]$.

Gronskij Aleksandr. 2005. Nacional'no-religioznoe napolnenie "Mužickoj pravdy". V: Materialy X Meždunarodnyh Kirillo-Mefodievskih čtenij, v 2 č. Minsk [Гронский Александр. 2005. Национально-религиозное наполнение “Мужицкой правды”. В: Материалы Х Международных Кирилло-Мефодиевских чтений, в 2 ч. Минск]. 
Haǔstovič Mìkola. 1999. “Câper maskal' pâe mudragelikì svae”. "Spadčyna”№ 5-6 [Хay̆стовіч Мікола. 1999. "Цяпер маскаль пяе мудрагелікі свае”. “Спадчына” № 5-6].

Haǔstovìč Mìkola. 2017. Dasledavannì̀ matèryâly: Litaratura Belarusì XIX - pačatku XX stagoddzâ, tom trècì. Warszawa [Хаўстовіч Мікола. 2017. Даследаванні і матэрыялы: Літаратура Беларусі XIX - пачатку XX стагоддзя, том трэці. Warszawa].

Hutorka staroho dzieda. 1861. “Dziennik Literacki” nr 89 (8 listopada).

Ìvanova Lûdmìla. 2013. Ukraïns'ke pitannâ v pol's'komu povstannì 1863 r. "Êvropejs'kì perspektivi” № 12 [Іванова Людміла. 2013. Українське питання в польському повстанні 1863 р. “Європейські перспективи” № 12].

Janulaitis Augustinas. 1925. Spausdintieji ir nespausdintieji 1863-64 m. sukiłimo raśtai [w:] Karo Archyvas, t. 1: 216-219.

Kanapackì Macej. 1961. Nad Memuaramì Bruna Karatynskaga. „Nìva” № 41 [Канапацкі Мацей. 1961. Над мемуарамі Бруна Каратынскага. „Ніва” № 41].

Karatynskì Vìncès'. 1922. Z GUTARKì STAROGA DZEDA. U: Garèckì Maksìm. 1922. Hrystamatyâ belaruskae litèratury. XI vek - 1905 god. Vìl'nâ [Каратынскі Вінцэсь. 1922. 3 ГуТАРКІ СТАРОГА ДЗЕДА. У: Гарэцкі Максім. 1922. Хрыстаматыя беларускае літэратуры. ХІ век - 1905 год. Вільня].

Karatynskì Vìncès'. 1981. Tvory. Mìnsk [Каратынскі Вінцэсь. 1981. Творы. Мінск].

Karatynskì Vìncès'. 1994. Tvory. Mìnsk [Каратынскі Вінцэсь. 1994. Творы. Мінск].

Karskìj Efimìj. 1903. Bělorussy, t. I: Vvedenìe v izučenìe âzyka i narodnoj slovesnosti, s priloženìem dvuh kart. Varšava [Карскій Ефимій. 1903. Бълоруссы, т. I: Введеніе въ изученіе языка и народной словесности, съ приложеніемъ двухъ картъ. Варшава].

Karskìj Efimìj. 1922. Bělorusy, t. III: Očerki slovesnosti běloruskago plemeni, č. 3: Hudožestvennaâ literatura na narodnom âzykě. Petrograd [Карскій Ефимій. 1922. Бплорусы, т. III: Очерки словесности бплорускаго племени, ч. 3: Художественная литература на народномъ языкп. Петроградъ].

Katalog dzieł znajdujących się w księgarni N. Kamieńskiego i Spółki w Poznaniu ( $w$ bazarze). 1858. Poznań: Nakładem i czcionkami N. Kamieńskiego i Spółki.

Kìsâlëǔ Genadz'. 1961. V. Dunìn-Marcìnkevič ì paǔstanne 1863 g. "Polymâ" № 5 [Кісялёy̆ Генадзь. 1961. В. Дунін-Марцінкевіч і паўстанне 1863 г. "Полымя" № 5].

Kìsâlëǔ Genadz'. 1963. Sejbitty večnaga: artykuly pra belaruskìh pìs'mennìkaǔ ì dzeâčaǔ rèvalûcyjnaga ruhu 1863 goda. Mìnsk [Кісялёў Генадзь. 1963. Сейбіты вечнага: артыкулы пра беларускіх пісьменнікаў і дзеячаў рэвалющыйнага руху 1863 года. Мінск].

Kìsâlëǔ Genadz'. 1971. Zagadka belaruskaj ÈNEìDY. Mìnsk [Кісялёy̆ Генадзь. 1971. Загадка беларускай ЭнЕгды. Мінск].

Kìsâlëǔ Genadz'. 2007. Agìtacyjnaâ publìcystyka 1860-h gadoǔ. U: Gìstoryâ belaruskaj lìtaratury XI-XIX stagoddzâu u dvuh tamah. T. 2: Novâ̂ litaratura: drugâ̂ palova XVIII - XIX stagoddze. Mìnsk [Кісялёў Генадзь. 2007. Агітацыйная публіцыстыка 1860-х гадоў. У: Гісторыя беларускай літаратуры ХI-ХІХ стагоддзяў у двух тамах. Т. 2: Новая літаратура: другая палова XVIII - ХIX стагоддзе. Мінск].

Kìsâlëǔ Genadz'. 2009. Sejbìty večnaga: artykuly pra belaruskìhpìs'mennikaǔ ì dzeâčaǔ rèvalûcyjnaga rèvalûcyjnaga ruhu 1863 goda; Skarynaǔskâ̂ sìmvolika: vytokì, tradycyì, intèrprètacyì. Mìnsk [Кісялёy̆ Генадзь. 2009. Сейбіты вечнага: артыкулы пра беларускіх пісьменнікаў і дзеячаў рэвалюцыйнага руху 1863 года; Скарынаўская сімволіка: вытокі, традыцыі, інтэрпрэтацыі. Мінск].

Lietuvos valstybės istorijos archyvas (LVIA), f. 378: Kancelâriâ Vilenskogo, Kovenskogo i Grodnenskogo general-gubernatora. 1768-1915. Političeskij otdel. 1864, b. 106: o dvorânině Radomskoj gubernìi Opočinskago uězda Konstantině Lopateckom 
[LVIA, f. 378: Канцелярия Виленского, Ковенского и Гродненского генералгубернатора. 1768-1915. Политический отдел. 1864, b. 106: О дворянинп Радомской губерніи Опочинскаго упзда Константинп Лопатецкомъ].

Lietuvos valstybės istorijos archyvas (LVIA), f. 1248: Vremennyj polevoj auditoriat pri štabe komanduûsego vojskami Vilenskogo voennogo okruga (1863-1911), ap. 1: Sledstvennye dela učastnikov vosstaniâ 1863 g., b. 22: Dělo o poměŝicě vdově Bondzinskoj,dočeri eâ Ideli, dvorânině Kaminskom i poměŝikě Vasilevskom [LVIA, f. 1248: Временный полевой аудиториат при штабе командующего войсками Виленского военного округа (1863-1911), ар. 1: Следственные дела участников восстания 1863 г., b. 22: Дпло о помпщищп вдовп Бондзинской, дочери ея Идели, дворянинп Каминскомъ и помпщикп Василевскомъ].

Łukaszewicz L. 1860. Rys dziejów piśmiennictwa polskiego, wydanie drugie większe, uzupełnione i doprowadzone do roku 1860. Poznań: Nakładem i czcionkami N. Kamieńskiego i Spółki.

Luščyckì Ìvan. 1958. Narysy pa gìstoryì gramadska-palityčnaj ì filasofskaj dumkì ǔ Belarusì ǔ drugoj palavine XIX veku. Mìnsk [Лушчыцкі Іван. 1958. Нарысы na гісторыі грамадска-палітычнай і філасофскай думкі ў Беларусі ў другой палавіне ХІХ веку. Мінск].

Mal'dzìs Adam. 1968. Tvorčae pabracìmstva: Belaruska-pol'skiâlitaraturnyâ ǔzaemasuvâzì ǔ XIX st. Mìnsk [Мальдзіс Адам. 1968. Творчае пабрацімства: Беларуска-польскія літаратурныя ўзаемасувязі ў ХІХ $\mathrm{cm}$. Мінск].

Mal'dzìs Adam. 1969. Litaratura XIX st. U: Gìstoryâ belaruskaj dakastryčnìckaj litaratury, t. 2: Lìtaratura XIX - pačatku XX st. Mìnsk [Мальдзіс Адам. 1969. Літаратура ХІХ ст. У: Гісторыя беларускай дакастрычніцкай літаратуры, т. 2: Літаратура XIX - пачатку XX ст. Мінск].

Méyet L. 1888. Wizerunki A. Mickiewicza. Zestawione i poprzedzone wstępem. Lwów.

Morozowa Olga. 1982. Bronisław Szwarce. Wrocław-Warszawa-Kraków-Gdańsk-Łódź.

Nastulczyk Tomasz. 2017. Gawęda starego dziada - Hutorka staroho dzieda: studium bibliograficzno-edytorskie literatury polsko-białoruskiej XIX wieku. Kraków.

Nevskaâ pisčebumažnaâ fabrika [Невская писчебумажная фабрика [online] https://ru. wikipedia.org/wiki/Невская_писчебумажная_фабрика [доступ: 20.07.2019].

Nowiński Franciszek. Stowarzyszenie studentów „Ogół” [online] http://www.polski petersburg.pl/hasla/stowarzyszenie-studentow-ogol [dostup: 26.06.2019].

Pavlovskìj I. 1843. Geografiâ Rossìjskoj imperii, čast' vtoraâ. Derpt [Павловскій И. 1843. Географія Россійской имперіи, часть вторая. Дерптъ].

Polski Słownik Biograficzny. 1939-1946. T. 5. Kraków.

Polski Słownik Biograficzny. 1971. T. XVI. Warszawa.

Revolûcionnyj pod"em v LITVE i Belorussii v 1861-1862 gg.. Materialy i dokumenty. 1964. Moskva [Революционный подъем в Литве и Белоруссии в 1861-1862 г2.. Материалы и документы. 1964. Москва].

Rossijskij gosudarstvennyjistoričeskij arhiv (RGIA), f. 1282, op. 1, d. 25 [Российский государственный исторический архив (РГИА), ф. 1282, оп. 1, д. 25].

Słownik geograficzny Królestwa Polskiego i innych krajów słowiańskich. 1882. T. III. Warszawa.

Słownik geograficzny Królestwa Polskiego i innych krajów słowiańskich. 1895. T.XIV. Warszawa.

Staronka vopìsu Bỉbliâtèkì B. Èpìmah-Šypily [u:] BDAMLM, f. 66, vop. 1, spr. 1429 [Старонка вопісу бібліятэкі Б. Эпімах-Шыпілы [у:] БДАМЛМ, ф. 66, воп. 1, спр. 1429, арк. 1 [online] http://archives.gov.by/index.php?id=964432 [доступ: 24.02.2020].

Szwarce Bronisław. 1893. Siedem lat w Szlyselburgu. Lwów.

Szwarce Bronisław. 1903. I. Założenie Komitetu Centralnego w r. 1862. W: W czterdziesta rocznicę Powstania Styczniowego. 1863-1903. Lwów. 
Šacillo M. 2003. Èvolûciâ nalogovoj sistemy Rossii v XIX veke. V: Èkonomičeskaâ istoriâ: Ežegodnik - 2002. Moskva [Шацилло М. 2003. Эволюция налоговой системы России в ХІХ веке. В: Экономическая история: Ежегодник - 2002. Москва [online] https://statehistory.ru/5537/Evolyutsiya-nalogovoy-sistemy-Rossii-v-XIX-ve ke/ [доступ: 25.06.2019].

Tal'virskaâ Zinaida. 1967. Nekotorye voprosy obŝestvennogo dviženiâ v LITVE i Belorussii $v$ konce 50-h - načale 60-h godov i podpol'nâ̂ literatura. V: Revolûcionnâ̂ Rossiâ i Revolûcionnâ̂ Pol'ša (vtoraâ polovina XIX v.): Sbornik statej. Moskva [Тальвирская Зинаида. 1967. Некоторые вопросы общественного движения в Литве и Белоруссии в конце 50-х - начале 60-х годов и подпольная литература. В: Революционная Россия и революционная Польша (вторая половина ХІХв.): Сборник статей. Москва].

Włodzimierz Aleksander Kurnatowski z Kurnatowic h. Łodzia [online] http://www.sejmwielki.pl/b/13.415.223 [dostup 29.06.2019].

Zakład Narodowy im. Ossolińskich (ZNiO), sygn. 14690, I i II.

Zalataâ kalekcyâ belaruskaj litaratury ǔ 50 tamah. T. 4: Litaratura drugoj palovy XIX stagoddzâ. Č 1 . Mìnsk [Залатая калекцыя беларускай літаратуры ў 50 тамах. Т. 4: Літаратура другой паловы ХІХ стагоддзя. Ч. 1. Мінск].

Zaporožec' Frem. 2013. Nastupaě tuča: Tuča prošedšyh i nastoâŝyh vremen. V: Ukraïns'ka ìdentičnist' ì movne pitannâ v Rosìjs'kìj ìmperï: Sproba deržavnogo regulûvannâ (1847-1914): Zbirnik dokumentiv ì materìaliv. Kiїv [Запорожець Фрем. 2013. Наступап туча: Туча прошедшых и настоящых времен. В: Українська ідентичність і мовне питання в Російській імперії: Спроба державного регулювання (1847-1914): Збірник документів і матеріалів. Київ].

Zemkevič Ramual'd. 1918. Staraâbelaruskâ̂ pis'mennas'c': Z arhìvu Romual'da Zemkeviča. "Varta” № 1 [Земкевіч Рамуальд. 1918. Старая беларуская пісьменнасьць: З архіву Ромуальда Земкевіча. "Варта” № 1].

ABSTRACT: About thirty Belarusian-language texts of the Uprising of 1863 have survived up to this day. Our interest lay, first of all, in the history of these works, the problems of their textual analysis, as well as their attribution. We closely looked at all known and available lists of their publishers. This concerns the Conversation (Hutarka) of an old man, twenty-two lists of which (nineteen Belarusian, one Lithuanian and one Russian) have recently been published in a specialised book by Tomas Nastulchik. We used photocopies from T. Nastulchik's book as well as originals (or microfilms) from archival files, tried to identify the protograph of the Conversation..., or rather, the author's version of the work. As a result, we came to the conclusion that the preserved lists can be divided into five groups (some of which include two, three or four edited versions of the text). This may mean that, on the basis of the author's version, no less than five lists appeared, the scribes of which were in fact editors or even co-authors of our poet. We believe that some of the earliest, and thus the closest to the protograph, are the lists of the so-called "lithographed" groups. We did not raise the question of authorship due to the lack of necessary material, but we believe that the presence of a significant number of verbs with an infinitive postfix- "ci" in the lists of the "lithographed" and "PoznańLviv" groups directs our efforts to find the author among speakers of the Volkovysk-Bialystok dialect of the Belarusian language. Of course, K. Kalinouski may not be the author, but the significant similarity of the Conversation (Hutarka)... and the "Muzhytskaya Prauda" in many aspects of its ideological and artistic content allows us to look for the poet in the circle of his closest associates, both among the students of the St. Petersburg-Moscow youth and the Grodno 
insurgent organization. We considered it necessary to include Lithuanianlanguage versions of the Conversation (Hutarka) in our publication since we believe that the problem of attribution of the Belarusian work is closely connected to the Lithuanian text.

KEYWORDS: Uprising of 1863, Old Grandfather's Conversation, protograph, lists, editions, attribution.

STRESZCZENIE: Zachowało się około trzydziestu białoruskich tekstów z okresu Powstania 1863 r. W artykule główną uwagę zwrócono przede wszystkim na historię tych utworów, problemy tekstologii i atrybucji. Przeanalizowano uważnie dobrze znane i dostępne redakcje. Przede wszystkim dotyczy to Gawędy Starego Dziada, której dwadzieścia dwie wersje (dziewiętnaście białoruskich, dwie litewskie i rosyjska) zostały niedawno opublikowane w książce Tomasza Nastulczyka. Korzystając zarówno z fotokopii T. Nastulczyka, jak i oryginałów (lub mikrofilmów), spróbowano „odnaleźć” protograf Gawędy..., autorską wersję dzieła. W rezultacie zasugerowano, że znane wersje można podzielić na pięć grup (niektóre $\mathrm{z}$ nich mają dwie, trzy lub cztery edycje). Może to oznaczać, że z wersji autora wyłoniło się co najmniej pięć redakcji, których kopistami byli w rzeczywistości redaktorzy, a nawet współautorzy naszego poety. W wyniku analizy stwerdzono, że najbliżej protografu jest wariant tzw. grupy „litograficznej”. W tym artykule nie podnoszono kwestii autorstwa, ale obecność w wersjach grup „litografowanych” i „poznańsko-lwowskich” znacznej liczby czasowników z bezokolicznikiem na -ci kieruje nasze starania w poszukiwaniu autora na nosicieli dialektu wołkowysko-białostockiego. Oczywiście K. Kalinouski może nie być tym autorem, ale znaczące podobieństwo Gawędy... do „Mużyckiej Praudy” w wielu aspektach treści ideologicznych i artystycznych pozwala na poszukiwanie poety wśród jego najbliższych współpracowników, zarówno wśród młodzieży studenckiej w Petersburgu i Moskwie, jak i organizacji powstańczej na Grodzieńszczyźnie.

SŁOWA KLUCZOWE: Powstanie styczniowe, Gawęda Starego Dziada, protograf, spisy, wydania, atrybucja.

РэЗЮМЭ: Да нашага часу дайшлі блізу трыццаці беларускамоўных тэкстаў Паўстання 1863 г. У артыкуле нас у першую чаргу цікавілі пытанні гісторыі гэтых твораў, праблемы тэксталогіi, а таксама атрыбуцыі. Дык мы пільна прыглядаліся да ўсіх вядомых і даступных іхніх спісаў-рэдакцый. У першую чаргу сказанае датычыць Гутаркі старога дзеда, дваццаць два спісы якое (дзевятнаццаць беларускіх, два літоўскія і расейскі) нядаўна ў адмысловай кнізе выдаў Томаш Настульчык. Мы, выкарыстоўваючы як фотакопіі Т. Настульчыка, так і арыгіналы (ці мікрафільмы) з архіўных спраў, паспрабавалі “дашукацца" пратографа Гутаркі..., аўтарскага варыянта твора. У выніку прыйшлі да думкі, што захаваныя спісы магчыма падзяліць на пяць груп (асобныя з якіх маюць дзве, тры ці чатыры рэдакцыі). Гэта можа азначаць, што на падставе аўтарскага варыянта ўзнікла не менш за пяць спісаў, перапісвальнікі якіх з'яўляліся па сутнасці рэдактарамі ці нават сааўтарамі нашага паэта. Мы лічым, што адным з найбольш ранніх, а г. зн. і найбольш набліжаным да пратографа, з'яўляецца варыянт г. зв. “літаграфаванае” групы. Пытанне пра аўтарства ў дадзенай працы мы не ставім, але мяркуем, што наяўнасць у спісах “літаграфаванае”, а таксама “пазнанскальвоўскае" групаў значнае колькасці дзеясловаў з інфінітыўным суфіксам $\boldsymbol{c i}$ скіроўвае нашыя намаганні на пошук аўтара сярод носьбітаў ваўкавыска- 
66| М і кол а Х а ў с т о в і ч

беластоцкага дыялекту беларускае мовы. Вядома, К. Каліноўскі гэтым аўтарам можа і не быць, аднак значнае падабенства Гутаркі... да "Мужыцкае праўды” ў шмат якіх аспектах ідэйна-мастацкага зместу дазваляе шукаць паэта ў коле ягоных найбліжэйшых аднадумцаў як сярод студэнцкае пецярбургска-маскоўскае моладзі, так і Гродзенскае паўстанцкае арганізацыі.

КЛЮчАВыЯ СЛОВы: Паўстанне 1863 г., Гутарка старога Дзеда, пратограф, спісы, рэдакцыі, атрыбуцыя. 